\title{
VIDA DE UN MIGRANTE: A PROPOSITO DE FRONTERAS Y TRANSFORMACIONES CULTURALES -una aproximación teórica con una pizca de historias personales-
}

\author{
Omar Arrieta Chavarría1
} La afirmación de que el progreso es la marcha hacia la abundancia, la libertad y la felicidad, y de que estos tres objetivos están
fuertemente ligados entre sí no es más que una ideología constantemente desmentida por la historia.

\section{Resumen}

En este artículo expondremos la tesis de que pese al esfuerzo que se hace desde las buenas leyes y la buena academia para explicar los procesos que hoy están relacionados con esa visión de un mundo para todos, todavía estamos lejos de comprender la situación del ciudadano común y su vida cotidiana. Y que la vida de un hombre o una mujer común, es inseparable de su condición de migrante y, sin embargo, frente a esta condición tan natural, que debería de ser tan libre, tenemos un mundo lleno de fronteras que nos separan y no nos permiten crear verdaderos espacios de convivencia pacífica.

Queremos decir con esto que las leyes y la Constitución Política de un país como Costa Rica, presentan textos realmente maravillosos de respeto por el ciudadano de aquí o de cualquier parte del mundo; pero muchas veces el discurso oficial apuntan hacia modelos de sociedad o de vida que no necesariamente están en la mira de los ciudadanos de países como los del tercer mundo en general. Frente al discurso del estado-nación y sus leyes, y la buena teoría crítica, aun queda un espacio de incomunicación que debería transformarse en un espacio que ayude al buen vivir cotidiano de la humanidad. Este artículo es simplemente una reflexión respecto de las contradicciones arriba señaladas, y las pondremos en evidencia con ejemplos muy simples de la vida concreta del inmigrante nicaragüense que llega a vivir y a trabajar a Costa Rica.

\section{Palabras claves:}

Migrante- vida cotidiana - globalización- cosmopolitismo - colonialidad del poder ciudadanía global - modernidad - sujeto - biografías.

1 Catedrático. Escuela de Ciencias Geográficas, Universidad Nacional, Heredia. Costa Rica. Correo electrónico: oarrietac@gmail.com 


\begin{abstract}
In this article we expose the thesis that despite the efforts done from good laws and good Academy to explain the processes that today are related to that vision of a world for all, those efforts are still far from understanding the situation of ordinary people and everyday life. That the life of a man or a common woman, it is inseparable from their migrant status and, however, against this so natural that it should be as free condition, we have a world full of borders that separate us and do not allow us to create true peaceful coexistence. We want to say with this law and the Constitution of a country such as Costa Rica, they are really wonderful texts of respect for the citizen here or anywhere in the world; but many times the official discourse point to society or life models are not necessarily in the sights of the citizens of countries such as the third world in general. Faced with the speech of the nation-State and its laws, and good critical theory, still there are a space of lack of communication that should be transformed into a space that will help the everyday good live of humanity. This article is just a reflection with respect to the above-mentioned contradictions, and we will put them in evidence with very simple examples of the concrete life of the Nicaraguan immigrant who comes to live and work to Costa Rica.
\end{abstract}

\title{
Keywords:
}

Migrant - everyday life - globalization - cosmopolitism - coloniality of power - global citizenship - modernity - subject - biographies.

\section{Introducción}

\section{1}

Una de las palabras que más me gusta es “migrante” y algunos de sus derivados "migración”, cuando no hace referencia a: "te busca la migra”, o “pasa por migración antes de entrar a mi país”. Me gusta migrante o migración o migratorio como una condición de la vida, de todas las manifestaciones de la vida. Todos los seres vivos somos migrantes. Emigrar es el transitivo, el tránsito de migrar, del carácter migratorio de la vida. Pero, a veces, "emigrante” o "inmigrante”, me parecen inventos fáciles, ocurrencias sin sentido. Y cotidianamente, en la práctica, en la vida concreta, tenemos que hacerlo, movernos de un lugar a otro, hay un concepto que todos conocemos, el de migraciones pendulares, tan cotidianas en nuestras 
ciudades: nos movemos diariamente de la casa al trabajo y del trabajo al hogar, y en ese péndulo, lo familiar se nos vuelve extraño y lo extraño familiar. ¿Pero no es así naturalmente la vida? ¿Es que acaso no ha sido así siempre desde que aparecieron las primeras hordas del homo sapiens en África? Ese movimiento, tan natural, en el que lo familiar deviene extraño y lo extraño familiar, no es acaso una de las formas de estar vivos. ¿No es acaso allí en donde muchas veces encontramos el sentido de la vida?

Al emigrar abandono [abandonamos], dejo [dejamos], la familia, nuestro pueblo, nuestros afectos para buscar mejores medios de vida, y este asunto cuando es forzado o súbito, es doloroso. Pero, tendría que ser siempre así, ¿estaremos destinados a sufrir, a veces, por lo que dejamos o por lo que encontraremos al migrar?

¿De dónde emigro? De emigrante sólo me conmueve la cuarta acepción del DRAE (1992) “cambiar periódicamente de clima o localidad algunas especies animales, por exigencia de la alimentación o de la reproducción ¿Hacia dónde inmigro? llego a un lugar para establecerme en él. ¿Pero ese lugar me debería ser necesariamente ajeno? ¿Por qué es tan doloroso muchas veces insertarnos en otros espacios, en otras culturas, en otros lugares? Evidentemente existen causas psicológicas que lo explican, pero sigo creyendo firmemente (sin ser psicólogo) que el dolor o el sufrimiento del sujeto se explica por el desgarramiento afectivo que sufre al separarse forzada o súbitamente de su familia, de su entorno de lo que simbólicamente forma parte de su ser y por las agresiones que sufre al tener que insertarse forzadamente en otra cultura, vincularse a otro entorno, interactuar con otros que no lo aceptan, que lo miran como un intruso o como un extraño, y hay algo allí que internamente nos produce dolor y sufrimiento, pero que evidentemente podría cambiar si aceptáramos todos que como opción de nuestra libertad podríamos ser animales emigrantes, y a partir de allí, asumir con naturalidad lo familiar y lo extraño, lo propio y lo ajeno y con ello establecer permanentemente nuevos vínculos.

\section{2}

En este artículo expondremos la tesis de que pese al esfuerzo que se hace desde las buenas leyes y la buena academia para explicar los procesos que hoy están relacionados con esa visión de un mundo para todos, por ejemplo desde el cosmopolitismo crítico, o desde la teoría de la colonialidad del poder, todavía estamos lejos de comprender la situación del ciudadano común y su vida cotidiana. Y que la vida de un hombre o una mujer común, es inseparable muchas veces de su condición de migrante y, sin embargo, frente a esta condición tan natural, que debería de ser tan libre, tenemos un mundo lleno de fronteras que nos separan, nos balcanizan. Habitamos un modelo socio -político que nos empuja hacia el riesgo negativo y no a asumir riesgos positivos como dirían Beck y otros. Riesgos que nos permitirían al final de cuentas, contribuir a crear verdaderos espacios de convivencia pacífica. Queremos decir con esto que las leyes y la Constitución Política de 
un país como Costa Rica, presentan textos realmente maravillosos de respeto por el ciudadano de aquí o de cualquier parte del mundo; igualmente no dudamos para nada de la agudeza de Bourdieu o de Touraine para comprender el mundo en que vivimos, pero algunos de estos estudios muchas veces apuntan hacia modelos de sociedad o de vida que no necesariamente están en la mira de los ciudadanos de países como los del tercer mundo en general, o son modelos o estilos de vida que parten del pensamiento occidental a pesar de la crítica dura contra las limitaciones del paradigma positivista, y a pesar del interés por ejemplo de Beck, por construir un nuevo paradigma que explique la segunda modernidad con la participación de todas las culturas. En fin, frente al discurso del estado-nación y sus leyes, y la buena teoría crítica, aun queda un espacio de incomunicación que debería de transformarse en un espacio que ayude al buen vivir cotidiano de la humanidad. Este artículo es simplemente una reflexión respecto de las contradicciones arriba señaladas, y las pondremos en evidencia con ejemplos muy simples conjugando la buena teoría crítica, con el discurso político y las buenas intenciones de las leyes de un país que dice ser democrático y solidario como Costa Rica, frente a la vida concreta del inmigrante nicaragüense que viene a vivir y a trabajar en esta Nación.

\section{3}

[Un migrante no es un transeúnte ni un judío errante, pero todo migrante tiene algo de errante o transeúnte y todo transeúnte tendrá algo de migrante y de judío. La idea es que un migrante sale de un lugar con destino a otro (a veces ese destino no se sabe dónde está) para instalarse allí por alguna razón, mientras que el transeúnte puede ser, por ejemplo, aquel turista que pasa por el barrio antiguo de una ciudad un par de días y luego se marcha porque se terminó su paquete de viaje y vuelve a su lugar de origen. El turista es sólo un transeúnte enganchado al mundo global del "viaje ahora y pague después" o algo parecido, está articulado a una de las nuevas formas de vida del ciudadano del mundo posmoderno. Esto lo traemos a colación justamente porque muchos de los migrantes llegan a un país inicialmente como turistas, y ya desde esta condición normativamente muy semejante para todos, operan entre los Estados y en sus fronteras, formas desiguales de trato para los ciudadanos del mundo. La Ley de Migración (2009) vigente en Costa Rica, en el artículo 47 establece, por ejemplo, “directrices generales de visas de ingreso y 
permanencia para no residentes, para personas extranjeras provenientes de determinados países o zonas geográficas, con base en los acuerdos y tratados internacionales vigentes y en las razones de seguridad, conveniencia u oportunidad para el Estado costarricense". Fija... una clasificación geográfica en varios grupos de países. Los ciudadanos de países del primer grupo al que corresponden, entre otros, los estadounidenses, europeos, canadienses, mexicanos y panameños, pueden ingresar al País sin autorización o visado por un lapso de 90 días. Los ciudadanos del segundo grupo, como los ciudadanos de Guatemala, El Salvador, Honduras y Venezuela pueden hacerlo igualmente pero solo por 30 días. Los nacionales del tercer grupo de países solamente pueden ingresar por 30 días y con visa consular; en esta lista se encuentran, entre otros, los dominicanos, nicaragüenses, colombianos y ecuatorianos. El cuarto grupo corresponde al listado de países con visa restringida o "consultada", esto significaba que requieren de una autorización emitida por la Dirección de Migración, previa valoración de la Comisión Consultora de Visas Restringidas y de Refugio, este grupo lo integran cubanos, haitianos, chinos e iraníes, entre otros”. Muchos de estos visitantes inician de esta manera su proceso de inserción en el país, pues aprovechan su condición de turista para comenzar negocios o para crear las condiciones que les permitan asentarse de forma permanente, negocios que, en principio, se describen como ilegales en la Ley que los ampara como turistas (Badilla, s.f.).

\section{$* * *$}

En nuestras primeras clases de fundamentos de filosofía el profesor nos habló de Diógenes el cínico, e hizo referencia a la imagen del judío errante como ciudadano del mundo, esto fue en 1970, entonces "el planeta no era tan global o posmoderno", y el tema de las migraciones y la ciudadanía global no estaba en la agenda de los estudios de filosofía de aquella clase. La leyenda del judío errante dice que este hombre está destinado a errar por el mundo por castigo de Dios. El judío errante no tiene ética ni moral que guíe su vida ni podrá recurrir a la moral que rige a las Naciones Unidas para salir de su condición humana lamentable. Pero si el judío errante fuese un seguidor del estoicismo (o el mundo fuera estoico), entonces simplemente se vería a sí mismo como perteneciente a la 
Kosmou Polités ${ }^{2}$ y probablemente no se sentiría un extraño o un ser deleznable como se estereotipa en la leyenda, aunque muchos lo viesen de esa forma. Entonces, la relación del individuo con el mundo que vive, con las estructuras societales, con la cultura en la que habita, o por la que pasa fugazmente, que ya desde los estoicos era una cuestión local global (el marco de la razón estoica), haría que este personaje se disolviera entre la maraña de ciudadanos del planeta y él y yo y el otro seríamos uno y distintos, porque el judío errante aunque tiene una identidad, pertenece a una familia, a una tribu, a una cultura y a una Nación, llevaría además siempre consigo el convencimiento de que pertenece al mundo y el mundo le pertenece.

Y si, siguiendo con este ejemplo, para viajar hoy el señor errante utilizara una credit card y un paquete turístico, eventualmente podría pertenecer a los ciudadanos del mundo que en el verano visitan los destinos paradisíacos del Caribe, es decir a la red global de ciudadanos que forman el club del jet set internacional posmoderno. Así el habitus ${ }^{3}$ el campo social, el capital simbólico ${ }^{4}$ y la trayectoria ${ }^{5}$, son categorías de análisis apropiadas

2 “Los estoicos, seguidores de Diógenes, desarrollaron su imagen del kosmou polités (ciudadano del mundo), aduciendo que cada uno de nosotros habita en dos comunidades: la comunidad local en la que nacemos, y la comunidad de deliberación y aspiraciones humanas que «es verdaderamente grande y verdaderamente común, en la que no miramos esta esquina ni aquella, sino que medimos las fronteras de nuestra nación por el sol» (Séneca, De otio).

Diógenes sabía que la invitación a pensar como ciudadano del mundo era, en cierto sentido, una invitación a exiliarse de la comodidad del patriotismo y de su sentimentalismo fácil; a considerar nuestros propios estilos de vida desde el punto de vista de la justicia y el bien. El accidente de dónde se ha nacido no es más que esto, un accidente; todo ser humano ha nacido en alguna nación. Una vez admitido esto, sostenían sus sucesores estoicos, no debemos permitir que diferencias de nacionalidad, de clase, de pertenencia étnica o incluso de género erijan fronteras entre nosotros y ante nuestros semejantes. Debemos reconocer la humanidad allá donde se encuentre, y conceder a sus ingredientes fundamentales, la razón y la capacidad moral, nuestra mayor lealtad y respeto. (Nussbaum, 1999: 3,4)

3 El "habitus" es un cuerpo socializado, un cuerpo estructurado, un cuerpo que se ha incorporado a las estructuras inmanentes de un mundo o de un sector particular de este mundo, de un campo, y que estructura la percepción de este mundo y también la acción en este mundo. En contraposición a la idea de acción humana por "interés" (que se fundamenta en el cálculo) y que estaría referida al abuso de las reglas de un campo específico: el económico, aplicadas a otros campos de las acciones humanas. Bordieu lo que nos dice es que está en contra de las teorías de la acción humana por interés, y propone en cambio la idea de habitus en su teoría de la acción con el fin de mostrar que la mayor parte de las acciones humanas tienen como principio algo que está muy lejos de la intención, es decir, se trata de disposiciones adquiridas que hacen que la acción pueda y tenga que ser interpretada como orientada hacia tal o cual fin sin que quepa plantear por ello que como principio tenía el propósito consciente tal fin. En el "juego", dice Bordieu, los jugadores, una vez interiorizadas las reglas, actúan conforme a ellas sin reflexionar sobre ellas ni cuestionárselas. La interiorización y automatismo de las reglas de juego, que son las que determinan la capacidad de acción de los jugadores, se corresponden con ese "cuerpo socializado", con el habitus generado en los diversos campos sociales. Entonces, de lo que se trata es de tener claro quiénes están jugando; cuál es el espacio en el que se desarrolla el juego (campo) y, deducir de las acciones qué tipo de juego es el que practican. (Bordieu, 1997, p. 166ss). [Las negritas son mías].

4 El capital es lo que cada individuo posee o anhela poseer: cierta posición social (capital social), bienes materiales (capital económico), conocimientos (capital cultural) o determinada valoración del mundo (capital simbólico). Entonces, los campos de la actividad humana se delimitan según prevalezca en ellos alguno de estos tipos de capital. En el campo del poder estos capitales se encuentran en tensión, ejerciendo presiones unos sobre otros. Los tipos de capital se encuentran interrelacionados; así, por ejemplo, quien sea rico en capital económico, también lo será en capital social, ocupando una posición dominante tanto en el campo económico como en el social. El capital simbólico es, al parecer, el de más difícil adquisición, pues es imposible heredarlo, como el económico: se aprehende luego de un proceso de formación. El "capital simbólico" es una propiedad cualquiera, fuerza física, valor guerrero, [o el honor] que, percibida por unos agentes sociales dotados de las categorías de percepción y de valoración que permiten percibirla, conocerla y reconocerla, se vuelve simbólicamente eficiente, como una verdadera fuerza

Geo UERJ - Ano 13, nº. 22, v. 1, $1^{\circ}$ semestre de 2011 - ISSN 1981-9021 http://www.e-publicacoes.uerj.br/index.php/geouerj 
para comprender a ese hombre errante de hoy, que a veces es un migrante y a veces solo un transeúnte. Entonces, las diferencias entre “errabundos” y migrantes podrían ser sólo una cuestión de tiempo y espacio, una cuestión histórica, un asunto de inserción en el proceso de circulación de pasajeros del mundo, de vínculos a una estructura productiva local global. En fin, un instante de los individuos en la flecha del tiempo, con la pequeña salvedad de que no es lo mismo pertenecer al jet set internacional, que al grupo de jornaleros agrícolas que diariamente se mojan la espalda pasando el Río Grande. De nuevo: en el planeta todos somos iguales, pero diferentes, es decir, ¿hasta dónde para los unos y para las otras, las libertades individuales son iguales, los derechos ciudadanos son los mismos, hasta dónde el reino de la justicia es ciego cuando las necesidades reales o artificiales son distintas? El Artículo 47 de la Ley de migración y extranjería nos ilustra sobre la existencia de las diferencias y de la concepción desigual que los estados-nación tienen sobre los ciudadanos del mundo, y de lo delicado y complejo que es este tema hoy. ${ }^{6}$.

\section{4}

El proceso de globalización entraña una interdependencia de las sociedades, desde lo económico a lo socio-cultural, laboral, político, tecnológico-ambiental. Analizar separadamente cada una de estas perspectivas puede ser un buen objetivo pedagógico, pero

mágica: una propiedad que, porque responde a unas "expectativas colectivas", socialmente constituidas, a unas creencias, ejerce una especie de acción a distancia, sin contacto físico (Bordieu, 1997, pp. 171-172). Es decir, el capital simbólico solo existe si es percibido por los otros como un valor [poder], sin existencia real, que se basa en el reconocimiento por parte de los otros.

5 Bourdieu (1997) utiliza el concepto de trayectoria para dejar claro el dinamismo del concepto de hatitus: "Toda trayectoria social debe ser comprendida como una manera singular de recorrer el espacio social, donde se expresan las disposiciones del habitus" (384). Sin embargo, cada posición tomada en el campo es una exclusión de otras posiciones, por lo que a medida que se "recorre el espacio social", se da un envejecimiento social, una imposibilidad de volver atrás, de variar. Es en este sentido que el concepto de habitus es dialéctico pues se refiere a adquisiciones que nunca cesan, se mueven con cada nueva situación de vida. El habitus no llega a ser consciente, no es algo deliberadamente poseído ni utilizado. Es, ante todo, la interiorización y la incorporación en las estructuras mentales de los distintos tipos de capital, es pre-reflexivo. [Las negritas son mías].

6 En ese marco teórico que plantea Bordieu en donde "el campo" es el espacio social estructurado de posiciones e interacciones objetivas, es una red de relaciones de dominación o subordinación, de complementariedad o antagonismo, etc. entre posiciones. El espacio social, es un sistema de posiciones sociales que se definen unas en relación con otras, por ejemplo, autoridad - súbdito, jefe - subordinado, hombre - mujer, [extranjero turista global - extranjero trabajador temporal globalizado]. Así, "El campo", tiene propiedades que pueden ser analizadas independientemente de los agentes que se encuentra en él, son interacciones que se encuentran en la producción, distribución y apropiación de "un capital". De esta forma, los campos de las actividades humanas se delimitan de acuerdo con la presencia en ellos de alguno de estos tipos de "capital". En el campo [o la esfera, dirían otros] del poder los capitales están en tensión presionando unos sobre otros. La posición en "el campo" está determinada por "el habitus" cuya adquisición, nos dice el autor en Las reglas del arte, es dialéctica, se modifica en cada nueva situación que se vive [de turista internacional me transformo en inversionista internacional ilegal en un país en el que estoy de visita]. los campos son "universos sociales relativamente autónomos" (1997, p. 84). Es allí, en esos campos de fuerzas (la educación, la burocracia, el mundo de los intelectuales, el de la religión o el del arte, entre otros), específicos, estructurados conforme a conflictos característicos en los que se enfrentan diversas visiones que luchan por imponerse, a través de los conflictos particulares entre los agentes involucrados.(Ver, Bordieu, 1991;1996;1997)

Geo UERJ - Ano 13, nº. 22, v. 1, $1^{\circ}$ semestre de 2011 - ISSN 1981-9021

http://www.e-publicacoes.uerj.br/index.php/geouerj 
en escenarios referidos a procesos que interpretan los temas del desarrollo y bienestar nacional regional o local, integrar el análisis de los procesos y las perspectivas es esencial para evitar la miopía en que a veces se cae desde el análisis sectorial o particular, como en los enfoques reduccionistas.

Desde esta óptica es mucho más aprehensible el fenómeno de la globalización como un proceso “líquido”, “flexible”, que desnuda el aparato jurídico político de los estados nacionales y muestra impúdicamente las irregularidades, por ejemplo, en cuanto a las leyes de protección a los trabajadores migrantes, la protección del medio ambiente y las formas de entablar negocios entre las corporaciones transnacionales y los estados-nación que, eventualmente, se benefician de las irregularidades y la corrupción en un determinado país. Pero también existen formas invisibles de agresión social que ocurren con la globalización (los inmigrantes indocumentados por ejemplo) que hacen de la ciudadanía del mundo una broma de mal gusto, un buen principio ético pero nada más.

Los grandes temas de la sociología se enriquecen a partir de la preocupación que las ciencias sociales tienen durante todo el siglo veinte por los problemas de las relaciones de poder, de la cultura en general, y de las culturas populares (o subalternas) en específico, del impacto del proceso de globalización sobre la cuestión del Estado, y de lo local.

Pierre Bourdieu en varios de sus ensayos nos ayuda a entender las relaciones de poder en el seno de la sociedad a través de su concepto de cultura, y lo hace tratando de explicar la articulación de lo económico con lo simbólico. Interesa aquí la idea de Bourdieu de que las condiciones de vida distintas producen habitus distintos (Bourdieu, 1988).

En otra línea de razonamiento, “Zemelman plantea que los sujetos son producto histórico y productores de la historia, señalando que existe en los sujetos una doble realidad: la que se refiere a las condiciones estructurales: formas organizativas, patrones de comportamiento y otra que no es aprehensible conceptualmente y que privilegia la memoria, la experiencia, la conciencia y los mitos”(Torres y Torres, 2000). Y estas prácticas de las que nos habla Zemelman, citado por Torres y Torres, son las que nos explican la existencia de la sociedad, de la vida, las culturas, los encuentros, y la vida cotidiana. 
En este ensayo procuraremos vincular una comprensión laxa de lo que para nosotros es vida cotidiana, con una visión crítica de la concepción negativa del individuo, como ser migrante, y cómo estos dos conceptos vida cotidiana y migrante, desde nuestra propia lectura o visión crítica, modifican la idea de frontera en el marco de las transformaciones culturales.

Para ello iniciaremos exponiendo una breve crítica a la forma en que se conciben las fronteras hoy y cómo el trasvase de fronteras genera siempre transformaciones culturales. Esto a partir de una síntesis libre de las teorías que explican los procesos mencionados. Partiendo de que el mundo de hoy no solo se diferencia del mundo pasado por cuestiones geopolíticas, o del ejercicio del poder o de los contenidos de aquellas culturas, o en fin, de la etapa en la evolución histórica de la humanidad en que se desenvolvieron, sino que hoy nuestra cultura local (o, las culturas vernáculas) está permeada por los procesos de globalización neoliberal y específicamente por el desarrollo y la complejidad del mundo urbano.

\section{Sobre “fronteras" y “transformaciones culturales" hoy, en el marco de las teorías de la colonialidad, el cosmopolitismo y el sistema mundo y otras reflexiones libres.}

\subsection{Las fronteras humanas como fronteras políticas}

Los estudios sobre gobernanza local, soberanía de los estados-nacionales y globalización desde enfoques como los de Rojo, (2010), Lucque (2010), Viejo (2010), y otros que se especializan en el análisis de las relaciones internacionales y del papel que deberían jugar los Estados en estos asuntos, se ocupan con detenimiento por dilucidar además la cuestión de los derechos humanos del ciudadano, habitante local, pero que se supone, esta también protegido por la legislación de organismos e instituciones con competencias transnacionales (Beck, 2004; Concepción, 2010; Hernández, 2010). La globalización desde estos estudios, se explica porque las relaciones internacionales se multiplican causando una mayor interdependencia entre los estados y una disminución en 
el control de las actividades en general por parte del estado-nación. Además, la globalización en estos enfoques, se caracteriza porque se asume que con ella se superaron las distancias físicas, lo que hace que, entre otras cosas, la comunicación se torne inmediata, se intensifique el intercambio cultural y aparecen nuevos patrones comunes de conducta que dan lugar al surgimiento de una identidad global. De esta manera, se cuestionan las costumbres y tradiciones porque la movilidad humana no conoce límites, se crean nuevas instituciones internacionales, se fomenta la cooperación internacional y aparecen problemas globales que requieren soluciones globales. Es decir, hay en todo lo anterior un concepto de fronteras humanas con límites muy claros, aunque parecieran sin límites. Esto porque las fronteras humanas son de muchos tipos: las propias del individuo, las que marcan los colectivos de cualquier origen, las fronteras políticas, están también los límites del crecimiento que se impone el capitalismo en el proceso de acumulación y la circulación de mercancías, o en fin, en el proceso general de su existencia como modo de producción, cuyo ámbito (limite) de existencia es ahora flexible.

Es esta la idea múltiple de frontera de la que aquí partimos: los espacios se han vuelto comunes, el mercado no tiene fronteras y emerge una nueva división internacional del trabajo, la producción y circulación de mercancías (incluyendo a los seres humanos) es multinacional, pero, al mismo tiempo se afirman y persisten los chauvinismos, los nacionalismos enfermizos, el terrorismo glocal, el riesgo y el miedo.

\subsection{Las transformaciones culturales}

El sujeto solo existe como movimiento social dice en alguna parte de su libro Alain Touraine (2002:201ss) a propósito de su interés por recuperar en la crítica de la modernidad la relación entre razón y sujeto. La realidad social la construimos colectivamente cotidianamente. La sociedad nos construye y nosotros construimos la sociedad, somos sujetos en tanto nos miramos en el otro y el otro nos mira, y en nuestra relación con los otros y con nuestro entorno cultural y natural vamos construyendo nuestra subjetividad, nuestra realidad, nuestra biografía, nuestra historia personal, nuestra memoria, nuestra ideología. Bajo esta condición de individuos y en relación con los otros y las “estructuras” que componen la sociedad, emerge nuestra condición de sujetos y nuestras 
subjetividades. De esta manera comprendemos el mundo, el nuestro interior (el aquí) y el de afuera. Eso nos hace sujetos- sociales - culturales (llenos de significaciones simbólicas) - identitarios.

$\boldsymbol{E} \boldsymbol{I}$ individuo llega a ser persona en un contexto social y la sociedad sólo existe porque los individuos la construyen, la hacen real. El concepto de realidad es subjetivo y objetivo a la vez. Todas las teorías culturales serias parten de estas ideas. Entre el multiculturalismo, la colonialidad del poder, la hibridación o la hibridez, el cosmopolitismo, etc. la diferencia está, a nuestro juicio, en este aspecto particular, en la forma de la explicación de la construcción, del surgimiento de las subjetividades y de su relación con los otros y con las estructuras (jurídico políticas, ideológicas, estatales, transnacionales, artístico- culturales) de la sociedad: hibridación, pensamiento de frontera, pluriversalidad, universalidad, homogeneización cultural, cosmopolitismo, descolonialidad, hacen referencia crítica a estos procesos o relaciones entre sujetos, subjetividades, personas, etnias, poder, estado, sociedad, globalización, futuro.

Aunque nuestro punto de partida es el de los personajes reales, sujetos concretos que miramos en una ciudad y su cotidianeidad; como científicos, también partimos de la misma inquietud de la que parten los estudiosos de las relaciones internacionales, las ciencias sociales y la cultura en el mundo de hoy, y que Kwame Anthony Appiah citado por Enrique Mendieta (2010) ${ }^{7}$ ejemplifica muy bien: qué conceptos sería apropiado usar para afrontar los desafíos del mundo moderno: globalización, multiculturalismo o cosmopolitismo y Appiah opta por el concepto de cosmopolitismo cuyo significado reconoce que aun está en disputa, que puede ser entendido como un ideal, pero también como una postura particular, y señala un perfil de dos tendencias dentro del cosmopolitismo. La primera tendencia insiste con la idea de que tenemos "obligaciones" hacia los demás (el reconocimiento de la “otredad del otro”). La otra tendencia afirma que debemos "tomarnos en serio el valor no sólo de la vida humana sino también de vidas humanas particulares, lo que significa, en las prácticas y creencias que le dan significado” (xv) y, agrega Mendieta, sobre el texto de Appiah, “...Diferencia, dentro de lo humano,

\footnotetext{
7 Se refiere al texto de Appiah del 2006 titulado Cosmopolitismo: La ética en un mundo de extraños. Geo UERJ - Ano 13, nº. 22, v. 1, $1^{\circ}$ semestre de 2011 - ISSN 1981-9021 http://www.e-publicacoes.uerj.br/index.php/geouerj
} 
es, para esta segunda tendencia, un bien intrínseco y debe ser preservado, celebrado y principalmente- debe ser un bien del cual debemos aprender”. (p.41)

Frente al cosmopolitismo ingenuo o ideológico “..., que se niega a someter sus enunciados universalistas a la crítica,... se plantea el cosmopolitismo crítico, que también...Walter Mignolo ha articulado y defendido "mediante el entretejido de una historia crítica al colonialismo occidental y el conocimiento incisivo de figuras filosóficas claves del canon de la filosofía descolonial”. Según Mendieta, "Si el cosmopolitismo reflexivo reconoce su arraigamiento, su materialidad, en la forma de ciertas instituciones e historias, puede llegar a ser una forma de cosmopolitismo emancipatoria.” (Mendieta, 2010, pp.15ss). Sostengo (dice este autor) que “el cosmopolitismo dialógico es un cosmopolitismo maduro (Mündig) - es decir, un tipo de postura epistémica y moral hacia el mundo - que reconoce, que está al tanto de sus privilegios y por ende de sus límites; y que puede reflexionar sobre esto desde el punto de vista del otro, al cual intenta alcanzar y del cual y con el cual intenta aprender”. (Mendieta, 2010, p. 4)

Este cosmopolitismo crítico lo suscriben otros autores como Beck, Delanty (2008) e incluso, Nussbaum (1999), que, según Mendieta (2010) en el caso de esta autora, su propuesta es "un antídoto contra el arrogante e impaciente cosmopolitismo de Kant,... un espacio sin límites de razones y que, presuntamente, es no excluyente en cuanto a sus miembros". (pp. 4 -13)

En Nussbaum, (1999) aparecen personajes y etimologías significativas del mundo griego, nuestra propia lectura nos dice que Diógenes el cínico no sólo es citado allí por su pensamiento filosófico quizás a contrapelo de la idea general de que los griegos se sentían ciudadanos por pertenecer a la polis ${ }^{8}$, es decir a su localidad; esto es, los griegos pertenecían a una ciudad Estado y, de vez en cuando, a una cultura que iba más allá de la balcanización $^{9}$, término con el que hoy el pensamiento occidental greco - romano -

8 [Las polis (ciudades estado) se constituyeron como una unidad política, social y económica de Grecia, pero si bien compartían una lengua, religión común, lazos culturales y una identidad étnica e intelectual que exhibían con orgullo, los habitantes de estas ciudades no pudieron fundar un estado unificado. Existía una gran rivalidad entre las diferentes polis, ya que consideraban que el reducido tamaño de cada una era lo más idóneo para practicar una adecuada política.]

9 Término empleado para designar la fragmentación de un espacio político determinado en entidades políticas independientes que normalmente son hostiles entre sí. El empleo del concepto de "balcanización" subraya específicamente los efectos problemáticos y conflictivos que se derivan real o potencialmente, de dicha fragmentación....

La aplicación del concepto balcanización no se limita, sin embargo, al marco balcánico, ni siquiera al europeo, ni se restringe a un pasado histórico más o menos lejano. En este sentido se ha hablado, por ejemplo, de la balcanización de África para referirse a la Geo UERJ - Ano 13, nº. 22, v. 1, $1^{\circ}$ semestre de 2011 - ISSN 1981-9021

http://www.e-publicacoes.uerj.br/index.php/geouerj 
cristiano define los procesos de fragmentación política - conflictiva de los territorios y que se contrapone a la idea de, por ejemplo, pluri -versalidad de la que nos habla Mignolo (2008). Nuestra propia lectura nos dice que Diógenes también nos enseña hasta hoy las contradicciones de un pensamiento griego opuesto a sus ideas y que, en la práctica nos hereda la idea de balcanización con connotaciones perversas puesto que refieren de alguna manera a la separación entre Estados, a la necesidad de las fronteras y a la presencia amenazadora del vecino como un vecino conflictivo, extraño, ajeno, al que debemos someter desde las diversas formas de colonialidad.

Dice Said (2005) a propósito de una historia de colonización semejante a la sufrida por las culturas precolombinas en América:

“La parte menos benigna de esa aparición temprana de lo que hoy llamamos modernización fue aquella que también ejerció la denigración y la humillación consecuente de las culturas nativas y las lenguas de la India, algo que sería inculcado en la generaciones de jóvenes hindúes.

En este contexto emergen prácticas científicas como el orientalismo, que se abrió camino en todos los niveles de la cultura: la cultura de masas y la de élite; y, por supuesto, dio al mundo muchas cosas nuevas en el camino del conocimiento y el arte, pero también expresó y encarnó el poder colonizador de moldear - a partir de su perspectiva- la historia, la geografía, la lengua, la cultura e, incluso, la ontología del nativo”. (pp. 48,49)

Se trata de un período en la historia en la India, pero como prolongación de un proceso largo de sometimiento imperial y con consecuencias epistémicas hasta hoy. El procedimiento es dialécticamente cíclico (o en espiral) con nuevos ingredientes conforme se desarrolla la modernidad euro-centrista, ego-centrista y teo-centrista, y los efectos del poder colonizador europeo solo varían ligeramente en cuestiones accesorias, (no en lo

multiplicación de fronteras artificiales en el continente producidas durante el proceso descolonizador de la segunda mitad del siglo XX...

De forma similar, se ha aplicado el concepto de balcanización para describir la fragmentación de Centroamérica... desde los tiempos de la independencia, y para señalar cómo la división de esta región en Estados pequeños y débiles favorece la imposición de los intereses de los Estados Unidos en una zona geoestratégica de vital importancia para los intereses de Washington.

Pero, sin duda, los acontecimientos que más han reavivado la vigencia del concepto de balcanización y los riesgos que se asocian al mismo, han sido los generados por la desintegración de la antigua Yugoslavia, a partir de 1991... (Pereira, 2008:102,3) Geo UERJ - Ano 13, nº. 22, v. 1, $1^{\circ}$ semestre de 2011 - ISSN 1981-9021 http://www.e-publicacoes.uerj.br/index.php/geouerj 
esencial, es decir, no cambian en términos de la colonialidad del ser,) según los territorios y las resistencias desarrolladas a escala regional o local.

Detengámonos un momento en el fenómeno de la migración como un elemento muy propio de nuestra condición humana y como una opción de vida, para que lo veamos, aunque de manera suscinta, en un período de larga duración en una región de frontera que siempre nos ha interesado conocer. Empecemos por el principio:

Dentro del espacio mesoamericano ${ }^{10}$, la Gran Nicoya es un producto geográfico cultural de grupos étnicos “mexicas” (maribios o subtiabas, otomangues, otomíes, popolocas, mazatecas, chiapanecas, (véase, Ferrero, 2000:59ss, Ibarra, 2001) que se desplazaban por diversos motivos desde el centro y sur de México hacia el sur este del istmo centroamericano (los chorotega- mangue llegan a Nicoya en el 800 d. de C.). Se trata de un conglomerado de culturas provenientes de un tronco común (otomangue), que se fue diversificando lingüística, religiosa y, en fin, étnicamente. Lange (1994) argumenta que La Gran Nicoya fue un centro cultural que perduró por más de 2000 años y que mantuvo contactos y recibió influencias de otras culturas que la rodeaban. Estos "estados” y “cacicazgos” convivían en tiempos de guerra y en tiempos de paz, y por ambas razones, es decir, en cualquier caso, se producían intercambios culturales y diversos procesos de fusión cultural por transculturación o, en fin, por hibridación (N. García, 1990, 2004, 2007) ${ }^{11}$ como producto del intercambio comercial entre las diversas etnias (ver, por ejemplo, los estudios de Ferrero, 1979,1981; Borgino y Lauthelin, 1994; Chapman, 1960; Ibarra, 2001).

10 Mesoamérica se extiende en un arco que va desde el noroeste de lo que hoy es México y su Frontera con EEUU hasta el sur este en Centroamérica (que corresponde al noroeste de Costa Rica, lo que hoy es Guanacaste y el norte de Puntarenas). Estaba dividido según Kirchhoff [1943] citado por Ferrero (2000:52) en diez sub áreas culturales, la ubicada más al sur este de dicho arco físico geográfico corresponde a la Gran Nicoya, una región geográfico cultural que se extiende desde el Golfo de Fonseca hasta bahía Herradura.

11 Debemos aclarar que una serie de conceptos o categorías de análisis utilizados en los estudios culturales desde las ciencias sociales y las humanidades han sido valorados y criticados por sus aportes a la explicación o por ser insuficientes a la explicación de lo que llamaremos aquí arbitrariamente "fusión cultural". Los conceptos de hibridación o hibridez, desarrollados por García Canclini en sus estudios arriba citados no escapan a estas críticas, igual suerte corren conceptos como aculturación que es contrapuesto al de transculturación, o el concepto de mestizaje. Algunas veces se les critica por ser conceptos que surgen dentro del paradigma de la colonialidad del poder, eurocentristas, egocentristas o diluidores de las contradicciones de la totalidad, en otras ocasiones se les valora por el aporte a la comprensión de la resistencia, de la heterogeneidad y de la comprensión de la historia cultural de América Latina. Una síntesis de la revisión crítica de estos conceptos, hecha por diversos cientistas sociales y humanistas, aparecerá en la Tesis doctoral: La heterogeneidad en el pensamiento clásico latinoamericano: Sarmiento, Martí, Vasconcelos y Mariátegui, que está preparando para su defensa su autor Gerardo Morales García en el Doctorado de Estudios Latinoamericanos con Énfasis en Pensamiento Latinoamericano de la Facultad de Filosofía y Letras de la Universidad Nacional, Heredia, Costa Rica. 
Pero ya antes, es muy posible que desde el pleistoceno tardío "se haya producido la evolución de pequeñas bandas de cazadores y recolectores a sociedades agrícolas sedentarias” en una región mesoamericana central que luego sirvió de puente entre los grupos mexicanos, subtiabas, los chibchas de Suramérica y los Caribe, generándose de esta manera, hace más de tres mil años, una extensa red de intercambio en lo que hoy es América Central y el Caribe. En fin, La Gran Nicoya en la zona sur de América Central, en el siglo XVI, era parte del “escenario de la expansión de pujantes sociedades las cuales mantuvieron un delicado equilibrio con sus vecinos, con quienes muchas veces llegaron a la guerra. La mayor parte de la población se concentraba en las tierras agrícolas por excelencia, y su alrededores, y fue en ellas donde recibieron, con mayor ímpetu, el golpe de la conquista.” (Ibarra, 2001, p. 45). Se trataba ya desde entonces de "oleadas de inmigrantes”.

En un artículo publicado en el año 2000 (Arrieta), decíamos que en Guanacaste, desde el período colonial ha habido un proceso continuo de emigrantes nicaragüenses, que en aquel tiempo fue producto, como bien se documenta dentro de la historiografía nacional, de la actividad ganadera trashumante que desde la costa pacífica centroamericana a través del camino de mulas unía las provincias del Centro de América. Esto hizo que se establecieran fuertes lazos permanentes entre ciertas regiones del subcontinente, un caso particular, por ejemplo, fue el eje Granada, Rivas, Liberia y Nicoya que se convirtió en un territorio de libre paso para los trabajadores del arreo y labores de las haciendas ganaderas en esa subregión. (Ver entre otros Matarrita, 1980; Sequeira, 1985; Edelman, 1992, 2005; Cabrera, 2007).

Con este desarrollo de las actividades ganaderas y de las haciendas florecen también y se consolidan los asentamientos de población que darán origen a las ciudades (ver, entre otros, el estudio de García y Soto, (1980) y Cabrera (2007) para el caso de la ciudad de Liberia).

Estos procesos de desarrollo cíclico de las economías mercantiles y del posterior desarrollo del capitalismo, están acompañados de procesos de aparición de grupos socio étnicos y de las clases sociales, tal y como se plantea por los teóricos de la colonialidad del poder (Quijano,2000; Quintero, 2010; Gorfoguel,2010; Mignolo,2010) pero como vemos 
estos procesos no están separados de las formas de consolidación el capitalismo global tal y como es también explicado por la teoría del sistema mundo.

Es allí, en el pensamiento fronterizo, en la experiencia local de la periferia, donde las experiencias históricas se unen, es allí en donde se pueden crear horizontes de expectativas que nos permitan superar las ideas colonialistas que atrapan y alienan a los pueblos:

El “ espacio de la experiencia” y el "horizonte de expectativas” son di-versos, o mejor dicho pluri-versos - lo que cada historia local tiene en común con las otras es el hecho de que todas tienen que enfrentar la presencia inevitable del mundo moderno/ colonial y de sus diferenciales de poder, empezando por la clasificación racial y la clasificación del planeta ...De esta forma, la pluriversalidad de cada historia local y su relato de la descolonización se pueden conectar través de esta experiencia común y utilizarla como la base para una nueva lógica común del “conocer”: el pensamiento fronterizo. ... El pensamiento crítico fronterizo es entonces el método que conecta la pluri-versidad (diferentes historias coloniales atrapadas en la modernidad imperial) con el proyecto uni-versal de desprendimiento del horizonte imperial, de la retórica de la modernidad junto a la lógica de la colonialidad,... (Migolo, 2010: 120,22)

En el siguiente apartado contrastaremos esta forma de vida cotidiana, como la que se generó en las sociedades precolombinas o la sociedad colonial, en lo que se refiere al encuentro entre culturas o entre vecinos, con la vida cotidiana de un mundo dominado por el sistema capitalista mundial.

\section{Que es la vida cotidiana y como ha cambiado hoy en general.}

\subsection{La vida cotidiana}

Decía Agnes Heller en 1994, “...a la alienación de la vida cotidiana sucede la "apropiación" de la alienación. Esto conduciría a un vivir cotidiano sin complicaciones, plenamente adaptado y por Geo UERJ - Ano 13, nº. 22, v. 1, $1^{\circ}$ semestre de 2011 - ISSN 1981-9021 http://www.e-publicacoes.uerj.br/index.php/geouerj 
tanto, des-esencializado. No obstante, será de esta situación de donde se desprenderá el proceso de esencialización, es decir, de desalienación. Sólo que para que ello ocurra se precisa superar la condición de "propiedad privada". Necesariamente, los primeros liberados de la propiedad, esos -en definitiva- seres excepcionales, extra-ordinarios, sin propiedad privada, señalan en el horizonte de la humanidad la posibilidad del comunismo” (p. 55).

No vamos a disgregarnos en la definición de lo que entendemos como vida cotidiana (sin embargo, nuestras reflexiones como puntos de partida en este ensayo están influenciadas por Heller, 1994; Massey, 1995; Bordieu, 1988; 1991; 1992; 1997) sólo diremos que existen cientos de científicos que desde diversas disciplinas han trabajado con esta idea como una categoría que explica mucho de lo que es el objeto de las ciencias sociales en general.

Entendemos la vida cotidiana como la vida diaria, las experiencias vividas por los individuos (singulares y plurales) en relación con ellos y su entorno inmediato, su lugar, el espacio en el que viven, en el que se desplazan diariamente. Y en este caso particular, pretendemos entender cómo esta relación ha cambiado, es decir la relación con el lugar, que creemos no es solo un fijo sino que también está compuesto de flujos, y justamente, los seres humanos (o el ser humano) es allí, en el lugar de fijos y flujos, donde se realiza viviendo su lugar y conectado con el mundo.

Para nosotros, la vida cotidiana hoy no está separada de la presencia de los migrantes, la vida cotidiana, la de las experiencias individuales en la calle o en el barrio de las ciudades como lo plantean diversos estudiosos de la ciudad de hoy, incluye la presencia de los migrantes como una de las expresiones de lo global en el lugar. Y esta presencia también forma parte esencial de las ciudades centroamericanas, como ha sido siempre, como herencia del pasado y será en el futuro, lo que cambia es el contenido con la llegada de la modernidad.

\subsection{Como ha cambiado vida cotidiana hoy en general: Lo local - global y el espacio público de la ciudad para los migrantes.}


Con esta segunda modernidad, con la modernidad tardía o con el capitalismo global, "El espectacular ensanchamiento de los espacios culturales, económicos y sociales, no se ve acompañado de una amplitud de los “espacios políticos”, o un Estado cosmopolita ni nada semejante, que establezca las regulaciones de la vida social, es decir no existe el ámbito que promueva principios de convivencia (Rojo, 2010:35)

La crisis del Estado nacional en el marco de un capitalismo sin fronteras para su expansión, aunque celoso de sus fronteras de gestión (las naciones poderosas) obligaran, más temprano que tarde, a la recomposición del Estado nacional en su relación con la transnacionalización de las cosas, porque no se trata sólo de trans - nacionalidades, si no que se trata también de transnacionalización de relaciones económicas, sociales y culturales (gobernanza, migraciones, acumulación flexible, nueva internacionalización obrera, cosmopolitismo: Beck, 2004; Concepción, 2020; Delanty, 2008; Luque, 2010; De la Torre, (s.f.); Rojo, 2010; Viejo, 2010) y la disociación entre “soberanía” y “territorio” y la proliferación de los no lugares que son como intersticios, como espacios opacos (para seguir a M. Santos, 1996) en donde lo global y lo local aparecen como escenario de los ciudadanos del mundo.

En la base de la explicación de la cultura y el mundo cotidiano de hoy aparece no el relato simple de la relación “infra”- "supra”, si no la más compleja definición de la trama infra-supra que se genera con el posfordismo y la sociedad del riesgo que trae consigo. Hechos globales que son locales en tanto y cuanto el estado-nación deberá redefinir sus relaciones internas con lo regional y lo local, en una situación nueva en la que el mercado prima sobre la Constitución y se fortalece el Estado de excepción. El fenómeno de la globalización abarca todos los órdenes de la vida pública y privada, golpea al sujeto individual y colectivo. La globalización entre sus primeras tareas permea al Estado que se torna incapaz de responder a un conjunto de problemas que superan sus fronteras y que por consiguiente modifican la gobernanza global -local. Hoy, el escenario espacial por excelencia de lo global-local es la ciudad.

Castells y Borja (2002) exponen la idea de que las ciudades como construcción social, juegan un rol estratégico en la afirmación de las identidades locales y regionales en donde se conjugan los flujos y la singularidad del lugar o la experiencia local. Para ellos, el 
fenómeno urbano de hoy fragmenta a la ciudad social y espacialmente. El espacio de la ciudad de hoy es más segregado que nunca, parafraseándolos, diríamos que el espacio de los flujos en la ciudad es global, y el de los lugares, el de la vida cotidiana de la gente, es cada vez más segregado (y los más segregados son los migrantes aquí y en Europa), aunque Castells y Borja plantean que es allí, en la ciudad globalizada, en ese terreno, en donde hay mayores posibilidades de generar nuevas gobernanzas, inclusivas, multiculturales e integradas a lo global, cuestión que, desde nuestro punto de vista, aun está por verse en las ciudades centroamericanas.

Dice Enrique Rodríguez (1998) a propósito de su estudio sobre La Laguna, una ciudad intermedia española,...

"Hoy nos movemos a una velocidad a la que nuestros antepasados ni siquiera podían imaginar. Esta circunstancia ha obligado a la ciudad a transformarse con ese fin. El movimiento es lo que convierte a las calles en meros puentes entre lugares. Pierde con ello su función comunitaria, marco de relaciones sociales de todo tipo y su papel esencial en la trama urbana.

La subordinación de la calle al movimiento la convierte en un espacio neutro, tanto para los viandantes como para los conductores. Los primeros porque se mueven como autómatas entre la multitud, la soledad entre el gentío. La actitud es expectante ante sus iguales que ocupan las aceras y plazas y vigilante ante el tráfico. Cada vez menos el caminante es dueño de sus pasos”. (p. 1,2)

Este autor, inspirado en Alejando Rossi, ${ }^{12}$ a propósito de su interpretación de las calles de la ciudad nos dice que “... Unas son como la prolongación de nuestra intimidad, son bulliciosas y promiscuas, otras son como territorios extranjeros, ajenos y distantes. La desaparición de esas calles que nos acogen casi como una continuación de nuestra casa, que han visto generaciones y generaciones de niños y niñas jugando confirmará la crisis de la ciudad, mejor dicho, de la vida ciudadana.

Luego agrega, "Los barrios de las afueras, los suburbios, iguales en todas las ciudades, conforman lo que algunos autores llaman "la no ciudad". Lugares sin 
personalidad definida, nacidos como hongos después de la lluvia, y que no se incorporan a la ciudad, con lo cual no dejarán seña de identidad alguna.” (Rodríguez, Allí mismo)

Estas citas nos conducen a la nostalgia de un autor que añora cierta forma de la vida en la ciudad, esa ciudad a escala humana como dirían algunos urbanistas. Pero también nos hace reflexionar profundamente sobre la mirada misma del ciudadano que sabe que la ciudad es suya frente a la mirada del migrante que siente que no pertenece a aquella ciudad que también podría ser suya, si no estuviese de por medio el mundo de la exclusión, la fragmentación, de los barrios sin identidad, de las calles para los autómatas en lo que se han convertidos las ciudades de hoy. Los hongos después de la lluvia son los barrios en los que se insertan los inmigrantes, junto a los pobres nativos de las ciudades en los países del capitalismo dependiente. Y es allí donde se libran las batallas por la supervivencia, tanto de los nacionales como de los extranjeros, allí se despiertan también, los chauvinismos, los estereotipos. Se estigmatiza al inmigrante y se le considera la amenaza fantasma o, directamente, el enemigo. Y en ese proceso de sobrevivencia, en la lucha cotidiana, el inmigrante que se inserta en la economía más informal, se mueve de forma pendular en la ciudad; desde el hongo urbano en el que vive, hacia el centro separado en el que se realiza la acumulación y la circulación del capital global, en donde se encuentran los centros históricos de atracción para del turismo del credit card, allí se topan inmigrantes y turistas, con un capital cultural y con unas trayectorias totalmente distintas. El inmigrante ilegal o semi- ilegal que busca trabajo se desplaza hacia los nuevos espacios de la ciudad difusa en donde eventualmente aparece la chamba en los barrios residenciales, como jardinero o vigilante, vendedora informal o empleada doméstica; y si el sector de la construcción se dinamiza, tendrá tal vez la chance de emplearse temporalmente como obrero de la construcción.

\section{Los migrantes nicaragüenses en Costa Rica}

[En Costa Rica residen entre 500.000 y 800.000 nicaragüenses, unos 12.000 colombianos y cerca de 30.000 cubanos, según diversas estimaciones.] 
Si partimos de cierto constructivismo como el de Bourdieu que trata de aprehender las realidades sociales como construcciones históricas y cotidianas de actores individuales y colectivos dentro de un marco teórico que intenta superar las dicotomías de la vieja filosofía social: idealismo - materialismo, o entre lo colectivo y lo individual, aquello que supera, pues, el sicologismo o el individualismo metodológico por ejemplo. Y si a esto agregamos que la coyuntura no está totalmente separada de la "larga duración”, entonces podríamos entender mejor, lo esencial de los procesos migratorios y de la vida humana como proceso (como movimiento) e interacción de los individuos en sociedad.

En este apartado haremos una “combinación” de todo, es decir, hablaremos al mismo tiempo de los grandes períodos para entender un fenómeno de los períodos cortos (las migraciones en la crisis actual del modo de producción capitalista), analizaremos conjuntamente a los individuos, a la sociedad, al estado-nacional y al cosmopolitismo como una posición crítica frente a cierta legislación de los Estados -nacionales. Intentaremos, en fin, contrastar los diversos campos desde donde se originan diversos discursos. Es decir, hablaremos llanamente de construcciones históricas que tienden a distanciarse de la voluntad y el control de sus actores. Veremos cómo el mundo de hoy le debe mucho al mundo pasado, cómo existen formas sociales arcaicas que se reproducen o son apropiadas o se modifican en las prácticas de la vida cotidiana de esos actores individuales y colectivos y cómo se vislumbra el futuro. Hablaremos del mundo objetivado de las instituciones y las normas, por ejemplo, que actúan como limitantes o como posibilidad para la transformación y de los mundos subjetivos, interiorizados, que también son edificaciones logradas a través de la percepción, de la sensibilidad, del imaginario y del conocimiento. Todo en la línea del habitus de Bordieu y otras variaciones en el marco de la sociología constructivista. Hablaremos de intencionalidades sin intenciones, de regularidades sin sumisiones conscientes a una norma o Ley, de racionalidades sin cálculos, en fin, de causalidades no mecánicas. En los hechos de los que aquí trataremos, no se apostará por explicaciones deterministas desde estructuras inconscientes u objetivas, ni creemos que nos vamos a encontrar con un modelo consensual de sumisión a la Ley o a los valores que surgen desde, por ejemplo, la Constitución, ni encontraremos una explicación a partir de la suma de las decisiones individuales y racionales. 
Nos dice Bourdieu (1997), que la mayor parte de las obras humanas que solemos considerar como universales —derecho, ciencia, arte, moral, religión, etc.- son indisociables desde el punto de vista escolástico tanto de las condiciones económicas como de las condiciones sociales que las hacen posibles y que nada tienen de universal. Se han engendrado en estos universos sociales tan particulares que son los campos de producción cultural (campo jurídico, campo científico, campo artístico, campo filosófico, etc.) y en los que están comprometidos unos agentes que comparten el privilegio de luchar por el monopolio de lo universal y de contribuir así, poco o mucho, al progreso de las verdades y de los valores que son considerados, en cada momento, como universales, incluso eternos (p. 213)

\subsection{El discurso oficial de cara al inmigrante: "Status migratorio" y las subcategorías de residente de los ciudadanos que viven en Costa Rica $^{13}$}

El artículo 3 de la Ley General de Migración y Extranjería del 2009 indica textualmente:

"Mediante la presente Ley se regula el control de las personas migrantes y se fomenta la integración de estas a la sociedad, con base en los principios de respeto a la vida humana, a la diversidad cultural y de las personas, a la solidaridad, la equidad de género, así como a los derechos humanos garantizados en la Constitución Política, los tratados y los convenios internacionales debidamente suscritos, ratificados y vigentes en el país. La Dirección de Migración y Extranjería determinará las condiciones para el ingreso de personas no residentes al país; para ello, establecerá los criterios para la clasificación de visa restringida, visa consular e ingreso sin visa”.

13 Esta sección del ensayo es un esfuerzo por combinar el debate teórico conceptual con un pequeño trabajo de campo. La información que aparece en el texto es una síntesis de opiniones sobre diversos temas tratados de manera abierta con trabajadores nicaragüenses que hemos contactado a través de los estudios y vivencias que hemos tenido con ellos en los últimos diez años (ver, Arrieta, 2000). También durante los meses de Enero y Febrero del 2011, estuvimos visitando la zona norte del país, con el fin de conocer un poco más sobre la vida de los nicaragüenses que de forma legal o ilegal viven en nuestro país. Las entrevistas informales y las conversaciones abiertas que tuvimos con un grupo de 17 nicaragüenses durante estas últimas semanas nos han permitido contrastar su visión con la que tenemos en el mundo académico o la que existe en el discurso oficial. 
Y en el artículo 5 señala:

“La presente Ley fomentará la integración de las personas migrantes al desarrollo del país; para ello, la Dirección de Migración y Extranjería diseñará estrategias y políticas públicas dirigidas a fortalecer la sostenibilidad del Estado social de derecho. El Poder Ejecutivo, con apego a lo establecido en nuestra Constitución Política, los tratados y los convenios internacionales ratificados y vigentes en Costa Rica y en esta Ley, determinará la política migratoria de Estado, regulará la integración de las personas migrantes, respetará su cultura y favorecerá el desarrollo social, económico y cultural del país, en concordancia con la seguridad pública; también velará por la cohesión social y la seguridad jurídica de las personas extranjeras que habitan en el territorio nacional”.

En lo que a migrantes se refiere el artículo 6 de la misma Ley indica “que la política migratoria estará orientada a promover, regular, orientar y ordenar las dinámicas de inmigración y emigración, en forma tal que contribuyan al desarrollo nacional por medio del enriquecimiento económico social y cultural de la sociedad costarricense. Con ese propósito, se promoverá la regularización e integración de las comunidades inmigrantes en la sociedad costarricense, así como el establecimiento de mecanismos que permitan mantener y estimular el vínculo permanente entre la sociedad nacional y sus comunidades de emigrantes. Controlar el ingreso, la permanencia y salida de personas, en concordancia con las políticas de desarrollo nacional y seguridad pública. Orientar la inmigración a las áreas cuyo desarrollo se considere prioritario, hacia actividades y ramas económicas que resulten de interés para el Estado, de conformidad con el Plan nacional de desarrollo. Garantizar la protección, atención y defensa de las personas víctimas de la trata de personas y coordinar con las instituciones competentes tales garantías. Garantizar el cumplimiento de los derechos de las niñas, los niños y los adolescentes migrantes, de conformidad con las convenciones internacionales en esta materia. Se tendrá especialmente en cuenta el interés superior de estas personas.

En el artículo 7, señala entre otras cosas sobre el inmigrante:.. impulsar acciones binacionales o multinacionales con los países expulsores de población migrante tendientes 
a conseguir: La búsqueda de la complementariedad entre la mano de obra nacional y la migrante, en forma tal que no exista un desplazamiento de la mano de obra nacional por la incorporación de trabajadores inmigrantes. El respeto a los derechos humanos y las garantías constitucionales de toda persona extranjera que ingrese y permanezca en el país. La integración de las personas extranjeras en los procesos económicos, científicos, sociales, laborales, educativos, culturales y deportivos. El respeto a las costumbres, la convivencia pacífica y la diversidad de los habitantes. La facilitación necesaria de procesos de regularización de las personas que se encuentren en el territorio nacional, de conformidad con las políticas de desarrollo. La tramitación de toda gestión migratoria deberá garantizar el aseguramiento a la seguridad social por parte de las personas migrantes. Tal garantía obligará a que todo trámite migratorio deba contemplar, como uno de sus requisitos básicos, contar con los seguros que brinda la Caja Costarricense de Seguro Social (CCSS). El pleno respeto de las obligaciones internacionales en materia de derechos humanos y la protección internacional de los refugiados. El reconocimiento de la riqueza multicultural existente en el país y del desarrollo de las potencialidades de todas las personas.

En el artículo 8, se señala, entre otras cosas, que La planificación de la política migratoria deberá apoyarse tanto en instituciones públicas como privadas competentes; para ello, se tomarán en cuenta los siguientes insumos: Los planes de desarrollo nacional, regional o sectorial, así como los programas anuales operativos en relación con los recursos humanos calificados disponibles y los necesarios para su cumplimiento. ...

Por otro lado, la Ley del 2009, señala, en el artículo 94, las categorías especiales para algunos residentes temporales en el país, entre ellos se contemplan: Trabajadores transfronterizos. Trabajadores temporales. En el artículo 97 se define a los trabajadores fronterizos como aquellas... personas extranjeras vecinas de las zonas aledañas a las fronteras de Costa Rica, autorizadas por la Dirección General para ingresar al territorio nacional y así egresar de él, con el fin de realizar actividades asalariadas, autorizadas por la Dirección General, tomando como referencia, entre otros, los estudios técnicos aplicados por el Ministerio de Trabajo y Seguridad Social. Además de otras obligaciones establecidas por ley y el ordenamiento jurídico costarricense, estos trabajadores deberán cotizar para el sistema de seguridad social de la CCSS y el de Riesgos del Trabajo del Instituto Nacional de Seguros (INS). El artículo 98, define a los trabajadores temporales como aquellas... 
personas extranjeras a quienes la Dirección General les autorice el ingreso y la permanencia en el país y permanezcan en él con el objeto de desarrollar actividades económicas de carácter temporal, a solicitud de un interesado en el país o, del propio trabajador, fuera de él [el país]... En el artículo 99 se agrega que "Los trabajadores temporales podrán permanecer en el país por el plazo que determine la Dirección General. Solo podrán desarrollar actividades laborales remuneradas en los términos, las condiciones, las zonas y para los patronos que autorice la Dirección General, con base en las recomendaciones del Ministerio de Trabajo y Seguridad Social, el cual definirá, además, las actividades de carácter temporal en las que se requiera autorización de ingreso y permanencia de mano de obra extranjera, mediante la realización de estudios técnicos y de mercado que determinarán el contingente de trabajadores temporales necesarios. ...”.

El espíritu de la Ley, muchas veces es sólo eso: el espíritu de la Ley. Pero qué ocurre cuando existe un espacio de interacción social en el que todos los elementos convergen y se articulan, excepto uno: el carácter fronterizo de la comunidad que se divide por fronteras políticas, ideológico- culturales, por el mercado que segmenta socialmente, y por el espacio geográfico que como producto social también se fragmenta. ¿Qué posibilidades hay de promover la vida en común en un espacio geográfico (común), en un estado-nación particular, que tiene las características antes mencionadas, heredadas del mundo colonial, del neocolonialismo, del modo de producción capitalista dependiente como es Costa Rica?

En el siguiente apartado contrastaremos el espíritu de la ley, el papel del estado -nación y de sus investigaciones en relación al inmigrante, las explicaciones de la buena teoría crítica, y el mundo real, cotidiano, de los inmigrantes nicaragüenses en Costa Rica.

\subsection{Cuestiones generales sobre los inmigrantes nicaragüenses en Costa Rica}

Desde las ciencias sociales, en los últimos tres lustros ha aparecido una gran cantidad de estudios sobre la cuestión migratoria en Centroamérica, desde diversas temáticas, desde distintos enfoques y con diversos propósitos. Una enumeración rápida de los asuntos tratados incluiría temas como: tendencias en el comportamiento de las migraciones en la región; condiciones de salud y empleo de los inmigrantes; migraciones, 
desplazamientos forzados y derechos humanos; impacto de los procesos migratorios en las economías regionales; migraciones en el marco de la globalización económica; políticas de desarrollo, migraciones y su impacto en las economías locales; población, empleo, pobreza y necesidades básicas de los inmigrantes; la situación de la mujer migrante; pueblos indígenas y migración; migraciones y cuestiones culturales en general; migración política y seguridad; migraciones y redes sociales; migraciones y estrategias de sobrevivencia; migraciones y política internacional; migraciones geopolítica, fronteras y redes sociales. Muchos de estos estudios son extraordinarios informes técnicos solicitados por los organismos internacionales a los institutos de investigación social en la Región, otros son diagnósticos de situación. Algunos documentos presentan el formato de la investigación científica, a veces disciplinaria y a veces interdisciplinaria, y varios de ellos en el marco de la más pura investigación positivista cuantitativa con el fin de conocer las medias, las medianas, los porcentajes y los promedios de los ciudadanos; para que los Estados nacionales puedan con mayor precisión planificar el desarrollo de su economía por sectores, por regiones, desde las necesidades de las mujeres; para tener los registros en orden que nos garanticen una estrategia de desarrollo nacional con criterios de integración, de participación y de colaboración del inmigrante; para sostener las garantías sociales y las instituciones de bien social. Estos estudios, en general, nos han permitido tener una visión bastante precisa de la situación de los emigrantes en Centroamérica.

En el caso de los estudios realizados para Costa Rica, la gran mayoría de ellos se refieren a la llegada de Nicaragüenses al país en las últimas dos décadas, justo cuando el capitalismo entra en la crisis actual, cuando los problemas de la pobreza y de la escasez se agudizan en la Región y se asocian (a veces nos parece que de manera sospechosa), con los desastres naturales. Es decir, la naturaleza se convierte en la causante de la pobreza y si no, sí de seguro, de la agudización de la pobreza, aunque a algunos este argumento nos deje un tanto perplejos. Las investigaciones proliferan y con sus resultados podemos hacer un resumen de la situación del nicaragüense que vive en Costa Rica, y aparecen en ese resumen la confirmación de los hechos: desde 1990 (ver, entre otros, Alvarenga, 1997; 2000; Morales, 1999; 2007; Cranshaw y Morales, 1998; Morales y Castro, 2002), se confirma en el país que: 
1. La mayor concentración de población inmigrante se ubica en la Gran Área Metropolitana seguida por la zona fronteriza con Nicaragua. Se agrega a esto, que en el resto de país también hay áreas receptoras de inmigrantes pero en menor proporción que en las dos regiones mencionadas. Se trata de población que se ha ido asentando, algunos de forma definitiva, en las principales ciudades y centros poblados del país.

2. La forma de concentración de inmigrantes en la Región Central tiene un gran impacto en el desarrollo social y la vida comunitaria costarricense. Las mayores concentraciones de inmigrantes se encuentran en los suburbios pobres de la ciudad de San José y cantones de la periferia a la capital. Es en torno al Área Metropolitana de San José (AMSJ) en donde más se han desarrollado y consolidado en las últimas dos décadas los espacios para la reproducción social y las redes de apoyo de los nicaragüenses.

3. Es probable que el país esté muy cerca del límite de las posibilidades productivas y de equipamiento social, para incorporar a los inmigrantes ya que el indicador de desempleo es mayor entre nicaragüenses que entre costarricenses. La mayoría de los inmigrantes nicaragüenses se encuentran en edad reproductiva, son varones, aunque tiende a crecer la llegada de mujeres.

4. La inmigración ha contribuido a segmentar el mercado de trabajo en áreas urbanas. En áreas fuera de la Región Central (Atlántica, Huetar Norte y Pacífico Norte), la población nicaragüense se dedica predominantemente a actividades agrícolas y es mucho más flotante que la que se ha instalado en el Centro del territorio.

5. Las zonas de mayor ocupación por nicaragüenses son las de mayor vulnerabilidad, se trata de áreas periféricas con escasa infraestructura en la red de servicios y de bajo equipamiento social. Esto ocurre de manera general en el país, lo que agudiza los problemas de hacinamiento y empeora la calidad de vida de los asentamientos humanos. La pobreza consolida un círculo perverso en el que junto a la condiciones de degradación del entorno se incrementa la inseguridad ciudadana y las condiciones de riesgo para la población.

6. La presencia de gran parte de población indocumentada es un problema social del país en general, pero esto significa más bien un reto para una Nación respetuosa de 
los derechos humanos y que sabe del papel fundamental que juegan los nicaragüenses en el desarrollo de la economía nacional.

7. Aunque, en general, muchos de los migrantes son personas jóvenes y solas, tienen responsabilidades con su familia en Nicaragua o en Costa Rica y normalmente tienden a permanecer más o procuran residir permanentemente en el país.

8. Las principales actividades a las que se dedican las mujeres nicaragüenses son oficios domésticos y la limpieza de edificios y oficinas, los hombres se dedican principalmente a la vigilancia privada y al cuido de vehículos en las calles. Estas dos últimas, junto con la venta ambulante de artículos pirateados, son actividades del sector más informal y que proliferan en períodos de crisis económica, en donde compiten todos los trabajadores pobres, no importa la nacionalidad.

9. La situación de la mujer inmigrante es más compleja y desventajosa ya que mayoritariamente se ubica en actividades domésticas, de limpieza de edificios y oficinas y su inserción productiva es invisibilizada en una sociedad patriarcal, clasista y desigual. Esto afecta mucho más en términos laborales, psicológicos y en general la calidad de vida de las mujeres nicaragüenses y sus familias instaladas en el país.

\subsection{La Población nicaragüense en Costa Rica, el trabajo y la vida cotidiana con algunos comentarios al margen.}

\section{Una pizca de historias personales.}

El mundo de "los legales"

Cada año entre noviembre y diciembre oficialmente se trasladan trabajadores agrícolas nicaragüenses a Costa Rica para trabajar en la recolección de los productos en la región de Guanacaste, la Huetar Norte y en el interior del país. Por ejemplo el Ministerio del Trabajo de Nicaragua informaba en el 2010 en la prensa de aquel país que a través del convenio binacional, en noviembre habían ingresado 1433 trabajadores agrícolas para trabajar en la zafra y la empresas cultivadoras de melón en Costa Rica, vienen en calidad residente temporal mediante un contrato de trabajo que los liga por seis meses a dichas empresas. En 
el año 2009, según datos del MITRAB, nicaragüense, ingresaron más de 2000 trabajadores amparados en estos convenios. ... de acuerdo con los convenios, estas empresas vienen hasta el lugar de origen de la mano migrante temporal, les facilitan medios de transporte ida y regreso, les ayudan con el trámite migratorio y se les paga conforme las leyes laborales de Costa Rica, garantizando que los nicaragüenses gocen de todos los beneficios a los que tienen derecho los trabajadores en el vecino país. (Villarreal, 2010)

Cuando comentamos los artículos de la Nueva Ley de Migración (2009) con algunos nicaragüenses que tienen una mejor educación académica o técnica, con más de una década de vivir en Costa Rica y cuyo estatus migratorio es el de residentes temporales o permanentes, y vuelven la vista atrás, al recorrido que ya han hecho, entonces sus vidas se resumen en reflexiones como las de Humberto y Gustavo, dos mecánicos especializados que llegaron entre finales de los ochenta y principios de los noventa, a través de la selva y que mantienen vínculos muy fuertes con su país, pero se sienten costarricenses también. El resumen es este:

\footnotetext{
“Cuando sos pobre y extranjero en la ciudad, lo que tenés es un "status migratorio" una condición de existencia, sos una subcategoría de residente y sos y no sos un ser en (y de) la ciudad. No sos un ser porque no sos un ciudadano con plenos derechos y no sos de la ciudad porque sos un transeúnte, un migrante que estás aquí para cumplir un objetivo distinto (vos estas aquí para alimentarte y reproducirte) pero para ellos (nuestros patrones) vos estas aquí únicamente para cumplir con intereses de los empresarios que necesitan tener trabajadores para cumplir con la demanda del taller, como lo somos nosotros. Obviamente que nosotros estamos agradecidos con el país, con el patrón (dice Gustavo), con los clientes (dice Humberto), y con lo que con nuestro esfuerzo aquí hemos logrado, pero nuestra relación con el resto del mundo es mínima, lo que tenemos que tener presente siempre es que debemos cumplir al pie de la letra lo que dicen los papeles de migración, unas reglas de conducta específicas para vivir aquí y eso es todo, después usted juéguesela como pueda con su vida”.
}

Esta cita, que hemos recogido en momentos distintos y situaciones distintas, es la síntesis de la percepción de ambos, porque Humberto y Gustavo, a pesar de tener una vida (una biografía) o una trayectoria en lenguaje de Bourdieu muy parecida, no se conocen, porque las trayectorias teniendo, diríamos, algo de semejantes, también son complejas $e$ inciertas, para cada individuo: 
[Humberto tiene cuarenta y seis años y veintitrés de vivir en Costa Rica, al inicio de manera ilegal, cruzaba frecuentemente la frontera por la montaña para poder evadir el control de migración, su familia es de San Carlos de Nicaragua, tiene 17 hermanos, él y dos más ahora viven en el área metropolitana de Costa Rica. Hizo la escuela primaria en Nicaragua y en su adolescencia trabajó con su padre y sus hermanos aserrando maderas al sur de su país. Cuando llegó inicialmente a San José por medio de contactos familiares que aquí tenía, logró alojarse en una pieza de un barrio marginal de San José, e intentaba diariamente obtener empleo de ayudante de mecánico, que al inicio lo hacía de manera informal y ocasionalmente, complementaba sus ingresos vendiendo cosas en la calle que luego le permitieron llevar un curso corto de vendedor de libros con lo cual vendía libros de Océano y enciclopedias de cualquier origen. Pasó sus primeros cinco años (entre 1988 y 1992) moviéndose entre San José y San Carlos de Nicaragua por temporadas, al mismo tiempo adquiría libros de mecánica para ir mejorando su formación y como él dice, siempre estudiaba los manuales y revistas de este oficio. Logró hacerse de mejores herramientas para trabajar y alquiló un rancho de cinc en Guararí, allí puso su taller de mecánica y se trajo a su mujer de Nicaragua. En 1998, mediante el Régimen de Excepción Migratoria ${ }^{14}$, obtuvo su condición de residente temporal. Entre 1999 y el 2007 alquiló un lote grande en San Rafael de Heredia y construyó un galerón muy bien acondicionado como taller, se trajo a dos de sus hermanos para trabajar con él, a uno le compró un carro de carga para que apoyara las tareas del taller y para que hiciera sus propios fletes, el hermano menor era su asistente de mecánica. Humberto amplió su radio de trabajo, logró nuevos clientes y prosperó como pequeño empresario independiente. A finales del 2004, el dueño del lote en que había construido su taller, le pidió el lote y tres meses después tuvo que irse del lugar, sin ningún reconocimiento económico por parte del dueño de la propiedad. Actualmente Humberto tiene una red de clientes a los que atiende a domicilio y eventualmente lleva algunos autos a su viejo lote en Guararí “que adquirió en propiedad durante los siete años de vacas gordas y donde remodeló su rancho de cinc e hizo una casa decente”. Uno de sus hermanos es ahora taxista pirata y su hermano menor trabaja como chofer para una empresa repartidora de embutidos en el Valle Central.]

[Gustavo tiene cuarenta tres años y una biografía muy semejante a la de Humberto. Gustavo es originario de la Isla de Zapatera en el Lago Cocibolca, un lugar paradisiaco en donde aun vive toda su familia, incluso su hija de nueve años y su ex esposa. Al igual que Humberto, Gustavo llegó de forma ilegal cruzando la frontera entre la montaña y se instaló en un distrito al sur de San José con unos amigos de San Jorge de Rivas, un lugar aledaño al Cocibolca. Empezó de manera clandestina a laborar como ayudante en pequeños talleres mecánicos del sur de San José. Con sus primeros ahorros logró estudiar mecánica en algunos pequeños institutos del país. En 1998 se enroló con los testigos de Jehová y mediante sus vínculos con esta congregación logró una mayor estabilidad en su trabajo, fue allí en donde conoció a un mediano

14 Conocido también como Amnistía Migratoria, para los inmigrantes centroamericanos, radicados en Costa Rica desde antes de 9 de noviembre de 1998. Un beneficio que otorgó el país a los centroamericanos a raíz de los estragos producidos en la Región por el Huracán Mitch. Aunque no exactamente cubría a los desplazados directamente por los efectos del Huracán. Muchos nicaragüenses residentes o ilegales aquí, la conocen como la Ley de Amnistía, pero que realmente no es una ley.

Geo UERJ - Ano 13, nº. 22, v. 1, $1^{\circ}$ semestre de 2011 - ISSN 1981-9021

http://www.e-publicacoes.uerj.br/index.php/geouerj 
empresario Bosnio con el que se enroló para trabajar de manera fija en la mecánica. Mediante el Régimen de Excepción Migratoria ha logrado obtener su residencia permanente que debe renovar cada cinco años. La familia de Gustavo en Nicaragua es de extracción campesina y pescadores de agua dulce. Gustavo dejó La Isla porque allí no hay opciones de trabajo para él “yo o me dedicaba a sembrar plátanos en una pequeña propiedad familiar allí, o me hacia empleado de un restaurante o me iba a pescar, pero ninguna de estas ocupaciones me permitiría superarme o tener un futuro mejor para mí y para mi hija, así que decidí jugármela y venir a tantear aquí con lo que me gusta que es la mecánica, no me voy a trabajar a Nicaragua porque no me pagan lo que gano aquí.” Gustavo cada tres semanas y durante sus vacaciones, viaja a La Isla para estar allá con su familia. La red a la que se ha insertado en Costa Rica es la de los Testigos de Jehová y es un ser solitario que no tiene contactos con sus compatriotas en este país.]

Humberto y Gustavo son nicaragüenses, mecánicos, pertenecen a la misma congregación religiosa, funcionan en redes semejantes, viven y laboran en la misma zona geográfica, pero como señalamos antes, no se conocen. Es decir, las redes globales también se fragmentan; en otras palabras, por encima o por debajo de la red global esta la fragmentación de la vida cotidiana, de las trayectorias y lo habitus.

\section{El mundo de los ilegales}

A partir de la década de 1980 se incrementa el ingreso de nicaragüenses de forma ilegal al país, procurando encontrar mejores opciones de trabajo en Costa Rica. La mayoría de las personas que ingresan ilegalmente se emplean en el sector agrícola, principalmente los hombres por lo duro de las tareas en el campo. Eventualmente, para labores de recolección y empaque de algunos productos se emplean mujeres, sin embargo, la mayoría de ellas se ubican como empleadas domésticas en las ciudades de la región central del país. Una pequeña porción de las mujeres trabajan en las labores de limpieza de los edificios de empresas privadas o como empleadas en las pequeñas sodas o restaurantes de las mayores áreas urbanas del país.

El sector de La construcción es actualmente, según algunos entrevistados, la segunda actividad más importante de ocupación de varones nicaragüenses en el país, principalmente en los proyectos de desarrollo costero y en las ciudades grandes y cabeceras de cantón se emplean como albañiles, peones o ayudantes o en labores de vigilancia en las obras. 
Luego se ubican los hombres en actividades relacionadas con la reparación de calzado, electrodomésticos o como obreros no calificados en pequeños o medianos talleres industriales. Finalmente, tanto hombres como mujeres se ocupan de la venta ambulante de productos de uso diario en materiales de plástico o cuero, o se dedican a vender música y películas pirateadas en los alrededores de los mercados, ferias y fiestas de las ciudades y pueblos.

En un mundo patriarcal controlado por el mercado y en el que persisten grandes desigualdades de oportunidades, la mujer esta aun en gran desventaja y, entre ellas, la mujer nicaragüense suple a la mujer costarricense de clase media y alta para que esta última se realice en el trabajo profesional y en el ocio fuera del hogar.

Las mujeres nicaragüenses, con residencia temporal o permanente, se ubican, por razones socio económicas, en las escalas más bajas en cuanto a opciones para mejorar su calidad de vida, tienen menos posibilidades porque están limitadas en el acceso a la vivienda, a la creación de empresas familiares o al crédito para iniciar una actividad que les procure mayor independencia económica.

Las condiciones laborales del inmigrante ilegal nicaragüense son muchas veces inhumanas. En muchos lugares de las zonas agrícolas las condiciones de vida son insalubres, con salarios muy por debajo del mínimo legal, sin reconocimiento de horas extras y no cuentan con ningún beneficio como trabajadores ${ }^{15}$. Esto ocurre también con los obreros ilegales que se ubican en el sector de la construcción y en oficios semejantes en las ciudades y zonas de desarrollo costero, que como antes apuntamos, actualmente pueden constituir el grupo más grande de nicaragüenses ilegales en el país.

Un informe reciente aparecido en la prensa nicaragüense, opinaba de la siguiente manera:

“...se estima que aproximadamente 800 mil nicaragüenses radican temporal o permanentemente en Costa Rica, en busca de mejores oportunidades laborales y salariales, y también de empleo especialmente en el Área Metropolitana y la regiones Norte y del Caribe de ese país.

15 Ver, Arrieta, 2000. 
...se estima una ocupación de 2 millones de personas en el mercado laboral costarricense y, con un gran supuesto que la mitad del número de nicaragüenses emigrantes tiene un trabajo, fácilmente se podría afirmar que el 20 por ciento del empleo está ocupado por conciudadanos nuestros, que no compiten por empleo con los costarricenses debido a que el mercado laboral está muy segmentado: los nicas se emplean en puesto de trabajo que no son del agrado de los ticos, los nicas se emplean en actividades económicas que los ticos ya no quieren.

..., los trabajadores nicaragüenses en Costa Rica contribuyen a generar el $40 \%$ del PIB, contribuyen a generar una producción de 14 mil millones de dólares y aportan a la seguridad social.

Se estima que el $60 \%$ de los emigrantes se ubica en zonas urbanas, donde hay más mujeres que hombres porque se dedican a los trabajos domésticos y al comercio, y el $40 \%$ en zonas rurales. La formación escolar del $65 \%$ de los emigrantes es de secundaria completa e incompleta.

... el 25\% del total de las remesas provienen de Costa Rica, o sea un monto anual aproximado a 200 millones de dólares que reciben los familiares de los nicaragüenses que han emigrado para trabajar en forma temporal, semi-permanente y permanente en nuestro vecino del sur. ...” (Avendaño, 2010).

\section{Los trabajadores de la construcción, trabajadoras domesticas y otros múltiples oficios}

[Paola tiene 25 años de edad y tres de vivir en Costa Rica, se vino ilegalmente con su madrastra a trabajar en un pequeño restaurante de San José. Obtuvo su permiso de residencia temporal en febrero del 2011. Aquí conoció a Luis su actual pareja, otro nicaragüense que cuida una propiedad de un ciudadano estadounidense que por temporadas viene a vivir al país. Actualmente Paola trabaja en oficios domésticos por horas en residencias de clase media ubicadas en San José y Heredia, esto, según ella, le da mucha flexibilidad laboral, e inició estudios en un instituto técnico que ofrece educación académica de secundaria y enseñanza de otros oficios, ella pretende allí aprender computación, tiene problemas para continuar estudios de secundaria pues su título de primaria no lo tiene reconocido en este país y en el pasaporte aparece con un nombre distinto al de su diploma de sexto grado en Nicaragua, por ello piensa que aquí no podrá continuar con su formación académica. Luis, el compañero de Paola, es originario de Estelí, tiene 27 años de edad y está separado de su primera esposa y tiene dos hijos en Nicaragua. Además de cuidar de la residencia del 
americano rentista con lo cual obtiene a cambio alojamiento para él, su padre y Paola, trabaja a tiempo completo en un almacén de repuestos en San José. En noviembre del 2010 obtuvo un documento que lo acredita como residente temporal. Ambos cotizan para la Caja Costarricense del Seguro Social y el interés de esta joven pareja es obtener ingresos que les permitan ahorrar para comprar una propiedad en un pueblo cerca de Masaya de donde es oriunda Paola. Almanzor, el padre de Luis, se ocupa de mantener el jardín de la casa que les ha cedido el ciudadano estadounidense y es vigilante nocturno de una fábrica de pastas en Santo Domingo de Heredia. Nos cuenta Paola, que Almanzor, su suegro, no tiene los papeles en regla.]

[Dayana tiene 23 años, es soltera, viene de Ciudad Darío, tiene tres años de estar en el país, al inicio se vino para trabajar en oficios domésticos por horas en residencias particulares, actualmente trabaja atendiendo una pequeña soda al sur de Alajuela donde también labora la prima que le animó para venirse. Hace más o menos un año, obtuvo con el apoyo de sus patrones un permiso de residencia temporal que debe estar renovando periódicamente. Logró que su patrón le permita algunos días salir más temprano para ir a estudiar al Instituto en que conoció por casualidad a Paola, las dos estudian computación y hasta ahora se conocen.]

[Mario Santos tiene 26 años de edad, se vino la primera vez de Nicaragua cuando tenía 17 años, entró de manera ilegal por Peñas Blancas se instaló con sus amigos de Chinandega en la zona de Pavas, comenzó a trabajar como peón en las construcciones residenciales del sur de San José y perfeccionó su oficio de soldador, trabajó varios años en las cuadrillas de maestros de obra que fue conociendo con el tiempo y complementaba sus ingresos haciendo sus propios trabajos en el campo de la soldadura. A los veinte años conoció a un par de hermanas nicaragüenses que vivían en su mismo vecindario y un año después se juntó con la menor de ellas con la que actualmente tiene dos hijos nacidos en Costa Rica. Su compañera trabaja ocasionalmente en oficios domésticos. Actualmente Mario está vinculado como hacedor de todo en proyectos constructivos que maneja un joven arquitecto costarricense a quien conoció ejerciendo su oficio en la zona de San Antonio de Escazú en donde vive con su familia, esto le ha permitido tener una mayor estabilidad en el empleo que no siempre es bueno. Mario Santos no tiene una situación legal en Costa Rica y está pensando en iniciar trámites de regulación de su situación en el país, amparado en el hecho de que sus hijos nacieron en Costa Rica. No piensa mucho en su regreso a Nicaragua porque según él, en Chinandega no hay tanto trabajo en su campo, aunque frecuentemente viaja a visitar a toda su familia que aún vive allá.]

Del conjunto de entrevistas realizadas durante los meses de enero y febrero en las ciudades de Liberia y Heredia obtenemos la siguiente percepción de los propios inmigrantes nicaragüenses: 


\section{Trabajadores de la construcción, guardas, oficios domésticos y oficios misceláneos en empresas privadas:}

La mayoría de los hombres jóvenes (entre 17 y 25 años que viven de manera más permanente en Costa Rica se dedican a trabajar en la construcción. La mayoría de las mujeres jóvenes Nicaragüenses (entre 18 y 25 años) se dedican a los trabajos domésticos.

Los hombres que se ubican en estas actividades son jóvenes solteros o juntados con mujeres nicaragüenses o costarricenses, con intenciones de formar una vida familiar en Costa Rica o en Nicaragua. Las mujeres intentan además, aprovechar la estancia en el país para aprender otro oficio en institutos técnicos costarricenses. Muchas de ellas son madres solteras que tienen sus hijos en Nicaragua y siempre piensan en volver a su país.

\section{Trabajadores artesanos (ebanistas, carpinteros, y otros oficios artesanales semejantes) en situación semi ilegal.}

La mayoría son hombres muy jóvenes o de mediana edad que en general son errantes, es decir, se mueven de un país al otro, es muy frecuente encontrarlos en las pequeñas ciudades o cabeceras de cantón en el Guanacaste.

[Pedro Gaspar, tiene cuarenta y un años, nació en León es hijo de campesinos y estudio los primeros años de agronomía en una universidad en su país, pero luego se vio obligado a dejar los estudios por razones económicas. Se casó y tiene tres hijos que viven en su ciudad. Hace una década se separó y desde entonces dos o tres veces al año viaja a la provincia de Guanacaste, ha vivido en La Cruz, Liberia y Filadelfia. Nosotros lo encontramos en Febrero viviendo en Liberia, allí, cada día se trasladaba de un barrio a otro en busca de chamba, ha establecido una pequeña red de clientes a los que les resuelve problemas de fontanería, carpintería, albañilería, jardinería y cualquier otra cosa que se presente. Conoce a algunos nicaragüenses que tienen una situación de residencia más estable y que normalmente se dedican a tareas muy parecidas a las de él, allí con ellos, logra alojamiento pagando una suma pequeña. Durante la semana que lo conocimos Pedro Gaspar estuvo trabajando para tres familias en labores de albañilería y fontanería en los barrios de Liberia. El último día que estuvimos en Liberia, Margarita una mujer que le había dado empleo nos contó de lo buen trabajador, servicial y educado que era Pedro. Nos dijo Margarita que tres días antes le había entregado una grabadora porque le había dicho que él se la podía reparar. Ese día que hablamos con ella había recibido en la mañana la grabadora reparada por Danilo, el nicaragüense en donde se hospedaba Pedro. Pedro Gaspar esa madrugada había regresado a Nicaragua sin despedirse de nadie y dejando algunos trabajos colgando, es probable que antes de que termine el año aparezca de nuevo por la ciudad o en otro lugar de la frontera, ofreciendo sus servicios a los vecinos de algún barrio como lo ha hecho en los últimos años.] 


\section{Mecánicos automotrices y obreros de talleres metal mecánicos.}

En general, son nicaragüenses con una vida más estable, con una aceptable formación técnica, con permiso de trabajo o residentes, con familias establecidas en el país. La historia de Gustavo y Humberto arriba escrita resume las condiciones y las perspectivas de vida de este sector social de trabajadores inmigrantes.

\section{Trabajadores informales en actividades de pequeño comercio}

Aunque mayoritariamente son hombres hay un porcentaje importante de mujeres que se dedican al comercio callejero (personas mayoritariamente entre 25 y 40 años. Una gran mayoría de ellos son “ilegales”, los que trabajan informalmente en Guanacaste, están viajando frecuentemente a Nicaragua y se dedican a vender en las aceras contiguas a los mercados de ciudades cabeceras de cantón, normalmente productos pirateados.

\section{Trabajadores agrícolas temporales}

Mayoritariamente hombres dedicados a la recolección del café, la caña de azúcar y otros cultivos. Son trabajadores que tienen su residencia en Nicaragua pero temporalmente trabajan en Costa Rica, para mantener a sus familias en Nicaragua.

\section{Pequeño comercio legal.}

Se trata de tareas que realizan principalmente las mujeres jóvenes o de mediana edad, residentes en el país que se dedican a atender "sodas"16, pequeños comercios muy vinculados a sus coterráneos que viven en el país. Y con muy poca perspectiva de volver a Nicaragua. Es el caso de Dayana por ejemplo, arriba descrito.

\section{$* * *$}

El mercado de trabajo costarricense ha sufrido una contracción con la crisis actual del capitalismo. Tanto en el sector agrícola como en el de la construcción, lo cual afecta directamente las oportunidades de empleo para un inmigrante en condición de residencia temporal o permanente en el país. Es decir para un inmigrante legal, las condiciones para

16 Pequeños lugares comerciales en donde se ofrecen alimentos a precios populares. 
los ilegales son aún peores. Sin embargo la presencia de trabajadores nicaragüenses en actividades económicas antes señaladas sigue siendo importante en el país. En una entrevista realizada en enero de este año al jefe de migración en Liberia, señalaba que los datos que se manejan, en general, en el país referidos a la presencia de ochocientos mil nicaragüenses de los cuales trescientos mil están en condiciones de legalidad, se acerca mucho a la realidad que él conoce. Efectivamente, es muy probable, porque no hay cifras oficiales fidedignas, que el número de nicaragüenses ilegales en el país sigue creciendo, o al menos no tiende a disminuir. ${ }^{17}$

El mundo patriarcal controla el mundo de la mujer, a las migrantes nicaragüenses, por su situación socio económica y por su escasa formación académica o técnica se le ofrecen pocas opciones de trabajo, se limitan a ser empleadas domésticas, trabajadoras agrícolas, vendedoras ambulantes o trabajadoras de pequeños negocios comerciales de ventas de comida. No obstante el cambio de status migratorio como el sufrido recientemente por Xochitl, le permite trabajar como empleada doméstica flotante e imaginar la posibilidad de recibir alguna formación en una escuela técnica de Costa Rica. Nandayure en cambio, que es madre de cuatro hijos de escuela que viven en ciudad Darío, solo tiene opciones de trabajar ilegalmente como empleada doméstica, sin posibilidad de ser asegurada y a riesgo de que ella sea deportada y sus patrones a ser castigados por violación a los artículos 175 y siguientes de la Ley. $8764 .^{18}$

La realidad se parece un poco más al testimonio de Alvarenga, (s.f.)

"En la última década cientos de miles de nicaragüenses, huyendo de la miseria, han migrado a Costa Rica. Cruzando la frontera ilegalmente muchos han sido atrapados por las fuerzas de seguridad costarricenses y obligados a retornar a su país. Pero no

17 En la década del 90, el gobierno de Costa Rica decidió tomar más control frente al ingreso masivo de nicaragüenses al país, con el argumento no sólo de que esto amenazaba con restringir las oportunidades de empleo para los costarricenses, sino que además, se argumentaron temas como el riesgo de colapsar los servicios públicos en el país, como salud o educación. Por esta razón deciden en el 93, promover el estatus de legalización para los nicaragüenses ilegales y crear la Tarjeta Estacional de Trabajo mediante convenio firmado por el MITRAB, Y MTSS, de costa Rica. Además en 1995 se expulsaron de Costa Rica 46.000 nicaragüenses ilegales, sin que ninguna de estas medidas haya mermado sustancial la llegada de nicaragüenses al país.

18 en los que se señalan la obligación de patrones y personas físicas o jurídicas, para no contratar a trabajadores extranjeros que estén en el país de manera irregular, o aún con permanencia legal, sin estar habilitados o autorizados para ejercer dichas actividades. Quienes incumplan dicha disposición se exponen a una multa consistente entre dos y doce salarios bases. 
es extraño que quienes fracasan en este intento, reincidan en su transgresión a las normas migratorias costarricenses y, tampoco es extraño que, quienes exitosamente cruzan la frontera, retornen a su país una vez concluida la zafra, la recolección de frutos o de café o cuando sienten la urgencia de visitar a los hijos y padres que quedaron allá. Para quienes se han beneficiado de las amnistías migratorias, especialmente de la última decretada en noviembre de 1998, que posibilitó la legalización de cientos de miles de inmigrantes, el viaje de ida y regreso puede efectuarse en un cómodo bus que conduce de San José hasta Managua siempre que se cuente con el dinero requerido para pagar los impuestos demandados. De lo contrario, la única opción es retornar por los caminos de la ilegalidad: las disimuladas sendas en selvas y montañas, pasadizos secretos que los “coyotes” se han apropiado para convertirlos en su capital de trabajo...

La necesidad de brazos de la economía agrícola y de la construcción ha ofrecido a los nicaragüenses un trabajo que les permite resolver sus más perentorias necesidades, mientras la economía costarricense se ha expandido contando con abundante y barata mano de obra. Si bien la rama de la construcción es fundamentalmente masculina, mujeres inmigrantes se han sumado a los trabajos agrícolas, especialmente de recolección de frutas y han encontrado un espacio en un sector laboral exclusivamente femenino: el empleo doméstico.

La creciente ola migratoria ha estado acompañada de manifestaciones xenofóbicas por parte de la sociedad receptora que, si bien no son generalizadas, provienen de los diversos sectores sociales y forman parte en la actualidad de la vida cotidiana costarricense. Aunque Costa Rica es un país multiétnico, el mito de que los costarricenses son distintos al resto de los centroamericanos por cuanto, a diferencia de sus vecinos, constituyen una nación predominantemente "blanca" y por ello “superior”, ha servido de base para el rechazo de aquellos “otros”. ...

En el contexto de la actual crisis económica que atraviesa Costa Rica, se hace más evidente el temor a la competencia de los nicaragüenses, especialmente entre los sectores pobres que comparten con ellos los mismos nichos laborales. Además la poca capacidad de los migrantes de negociación de sus condiciones laborales, ha generado en los trabajadores costarricenses la sensación de que su miseria afecta 
negativamente las condiciones de trabajo de los considerados "legítimos" pobladores de la nación. ... Sin embargo, la economía costarricense se ha venido desarrollando en creciente dependencia de los inmigrantes en áreas claves como la construcción, la agricultura y, también, el proceso de integración de la mujer al mercado laboral, ha sido en buena medida posible gracias al servicio doméstico que hoy ofrecen, mayoritariamente las nicaragüenses. La dependencia de estas ramas de la economía de la mano de obra inmigrante permite afirmar que su retorno masivo sería catastrófico para la economía nacional.

Algunos nicaragüenses emigran para participar en actividades temporales retornando a su país cuando estas concluyen, otros se establecen en Costa Rica solos o con sus familias con la esperanza de regresar cuando la situación mejore y, un grupo importante de ellos, se decide por establecerse definitivamente. ... Los costarricenses tienen la opción de decidir si asumen estas transformaciones étnicas con la sabiduría cosmopolita que aconseja disfrutar y aprender de la otredad, o con la terquedad xenofóbica que puede conducir a una incontenible y absurda espiral de violencia” (Alvarenga, (s.f.).

$* * *$

El cambio de estatus migratorio del nicaragüense en Costa Rica, de ilegal a legal, ${ }^{\mathbf{1 9}}$ es un tema realmente apasionante y nuestra percepción es que tratándose de población migrante con bajos niveles de educación y ninguna formación técnica para incursionar en un segmento de mercado de mejores ingresos, el cambio de estatus jurídico del migrante no modifica en mucho su condición de trabajador, o de ciudadano o su vida cotidiana. Es por esa razón, que para nosotros es claro el comportamiento ambiguo, incierto, contradictorio del nicaragüense frente a su condición laboral, a su condición de ciudadano y como ser necesitado de servicios para la reproducción de su vida y la de su familia. En el horizonte del migrante lo que aparece a diario es su necesidad de tener un empleo para sobrevivir, no importa bajo qué condiciones aparezca el trabajo. Y obviamente, como todo ser humano

19 También se encuentran ciudadanos semi ilegales, son aquellas personas que teniendo un pasaporte este está vencido, su visa de permanencia en el país también lo está, o tienen alguna otra situación irregular o en trámite con miras a lograr un permiso temporal de trabajo. 
el migrante sueña con o busca la posibilidad de disfrutar de los servicios de salud, de la educación para sus hijos y de tener una vivienda para su familia.

Frente a estas necesidades lo que sigue predominando entre la población migrante nicaragüense es, en mucho, la desprotección laboral, y la dificultad o la imposibilidad de contribuir al mantenimiento de la seguridad social y los otros servicios que le ofrece la sociedad costarricense. La evasión en las planillas, las formas de subcontratación o contratación directa ilegal, el incumplimiento de las obligaciones sociales que la legislación laboral costarricense exige a los patronos y las limitaciones del Estado para ejercer una adecuada inspección en los centros de trabajo, sigue estando en la base de la explicación de los problemas con que se enfrenta el país y lo inmigrantes hasta el día de hoy. Hace más de una década los informes referidos a la situación del inmigrante nicaragüense, citados arriba, señalaban que el Estado costarricense debía avanzar hacia un tratamiento más integral de la inmigración, en busca de una mayor coherencia entre el tratamiento de los problemas migratorios y el manejo de las políticas nacionales y sectoriales en esta materia, sin embargo, la situación tres lustros después, sigue siendo la misma.

\section{Conclusiones: sobre el sujeto, la de -colonización y los espacios de libertad y el desmontaje de las teorías.}

Bordieu (1988a) dice que detrás de una trayectoria está presente un "habitus”, un sistema de disposiciones durables, traspasables, estructuras estructuradas dispuestas a funcionar como estructuras estructurantes, como principios de generación y estructuración de prácticas y representaciones, pero la vida cotidiana no tiene porqué condenar al sujeto a la mera pasividad. "La persona humana como totalidad no es una marioneta tirada por las cuerdas de la costumbre. Las normas necesitan interpretarse en contextos siempre nuevos, las personas deben tomar iniciativas en situaciones imprevistas; deben enfrentarse también a las catástrofes de la vida cotidiana" (Heller, 1991, p. 69 -70).

La trayectoria en Bordieu, va más allá de la simple proyección de la vida del sujeto a partir de su origen social, la trayectoria es también temporalidad de las experiencias vividas por los sujetos, sus historias sociales y sus biografías. Hoy, diversos grupos o 
sectores sociales desarrollan variadas formas estratégicas para la supervivencia, para mejorar o conservar su status migratorio, por ejemplo, hoy las trayectorias de un migrante son más complejas (social, económica y culturalmente), que antes. Igualmente ocurre con los sectores de clase o capas socialmente cohesionadas al interior de un país. El mundo globalizado tiende cada vez más a recrear prácticas traspasadas por los procesos de fragmentación social, espacial y cultural, bajo un entramado de recorridos novedosos, distintos, y que incluyen diversas estrategias para la reproducción de la vida de los individuos y de los grupos sociales en un territorio específico en donde juegan en primer lugar, el estado- nación, el poder y la dinámica cultural y la incertidumbre de la vida diaria.

Aquí hemos tratado de un sujeto cuya singularidad la definen otros: su condición de extranjero, de ilegal o indocumentado, de residente temporal o residente permanente. Un residente que muchas veces, escasamente reside. $\mathrm{Y}$ esto nos evoca de inmediato esa definición del cosmopolitismo como

“...el juego dialéctico entre singularidad y universalidad, fijeza y desplazamiento, arraigo y desarraigo, abogo y desamparo, inmovilidad y movilidad. Uno no puede tornarse cosmopolita sin separarse de una localidad ya sea espacial o temporal, porque ninguno de nosotros está arraigado sin más, sin un índice que se descifre en referencia a algún tipo de mirada del mapa global. Ser local significa ser parte de un mapa, un mapa que provee una mirada a la totalidad. Una localidad es una trayectoria de una distancia hacia un lugar y desde ese lugar devuelta hacia ese horizonte de distanciamiento.” (Mendieta, 2010, p.3)

Y Touraine nos recuerda que:

Sólo la idea de Sujeto puede crear no sólo un campo de acción personal sino, sobre todo, un espacio de libertad pública. Únicamente lograremos vivir juntos si reconocemos que nuestra tarea común estriba en combinar acción instrumental e identidad cultural, es decir, si cada uno de nosotros se construye como Sujeto y si nos damos leyes, instituciones y formas de organización social cuyo objetivo 
principal sea proteger nuestra exigencia de vivir como Sujetos de nuestra propia existencia.

No hay ninguna discontinuidad entre la idea de Sujeto y la de sociedad multicultural, porque sólo podemos vivir juntos con nuestras diferencias si mutuamente nos reconocemos como Sujetos.

¿Cómo combinar, pues, igualdad y diversidad? Mediante la asociación de democracia política y la diversidad cultural. No hay sociedad multicultural posible sin el recurso a un principio metasocial universalista, que no puede ser otro que los derechos humanos. Pero tampoco existe una sociedad multicultural posible si ese principio universalista impone una concepción de la organización social y de la vida personal que sea juzgada normal y superior a otras. La apelación a la libre construcción de la vida personal es el único principio universalista que no impone ninguna forma de organización social y de prácticas culturales.

Cuanto más se concibe la sociedad multicultural como un encuentro de culturas y comunidades, más posibilidades existen de provocar enfrentamientos peligrosos en torno a la inmigración. Y al contrario, cuanto más se intenta reunir culturas diferentes en la experiencia vivida y en el proyecto de vida de los individuos, mayores son las posibilidades de éxito. (Touraine, 1997)

Dentro la diversidad cultural costarricense se encuentra la población nicaragüense, que ha convivido con nosotros desde tiempos inmemoriales, desde las culturas precolombinas como ya explicamos anteriormente y particularmente los lazos de consanguineidad y étnicos con la provincia de Guanacaste han sido desde la historia precolonialista hasta hoy muy fuertes. La población nicaragüense ha participado de mil formas en la historia nacional, (en las cortes españoles de la época colonial, durante la guerra de 1856, en la construcción del ferrocarril al Atlántico, en las actividades bananeras del Caribe y el Pacífico Sur, y en la construcción de gran cantidad edificios de la Costa Rica de hoy).

Pero, entonces ¿por qué no funciona el cosmopolitismo crítico aquí, o el sueño de Nussbaum o el viejo anhelo de los estoicos griegos? ¿Por qué no surgen tan fácilmente los 
espacios de libertad? ¿Es que acaso no hemos aprendido de la nueva Europa de Habermas y Beck? ¿Es que acaso los europeos lo lograron ya o lo lograrán algún día? Será acaso sensato pensar en esa idea del cosmopolitismo supranacional de Habermas (1998), en el que un juez mundial juzgara y castigará a los Estados nacionales por ser el último obstáculo para alcanzar el sueño kantiano? Desde los hechos reales, concretos, cotidianos, desde la vieja Europa Beck (2004) nos dice, “de hecho, ya hoy se vislumbra una perversa combinación de la política de mundializar los mercados con la propagación de la xenofobia. Puertas afuera, frente a los mercados mundiales, el comportamiento es adaptativo; puertas adentro, autoritario. Para los vendedores de la globalización, lo pertinente es el neoliberalismo; para los perdedores de la globalización, avivar el miedo a lo extraño y suministrar dosificadamente el veneno de la reetnificación”. (380). Este veneno y esta xenofobia, se reproducen entre países perdedores de la globalización, porque aunque queramos o no, Nicaragua y Costa Rica siguen siendo perdedores, pero dentro de esa lógica del pensamiento colonial, de nuestro propio colonialismo interno, reproducimos aquí, en la frontera, en el pensamiento de frontera, el miedo a los extraños, sin darnos cuenta que al final de cuentas los extraños somos nosotros mismos. Tal vez sea cierto aquello de que El dominio legítimo de los derechos humanos no conoce fronteras, (Beck, 387) aunque en la vida cotidiana de un migrante del mundo (normalmente de aquello que solíamos llamar el tercer mundo) la frase suene hueca, aunque exista un orden militar global que por encima de las fronteras, acuda al llamado por la defensa de esos derechos. ¿En nombre de quién? (Beck, 2004). Y ahí está otro problema ¿cómo entienden la democracia los europeos? ¿Será el mismo concepto de democracia para todo el planeta? Porque, efectivamente, "sin democracia el cosmopolitismo muere antes de empezar a vivir" (Beck, 2004,402).

Walter Mignolo, 2010, nos sugiere algunas pistas para ver el mundo de otra forma:

“... La transmodernidad sería la orientación general para los proyectos de de-colonización y de desprendimiento, una orientación hacia la pluriversalidad como proyecto universal. El pensamiento fronterizo, una vez más, es uno de los métodos que pueden ayudarnos a desplazarnos hasta sostener una visión pluri-versal 
y no uni-versal e implementar estrategias para alcanzarlo. El futuro ya no sería regido por un sólo estilo de vida (la pensëe unique de Ramonet), no podría ser dictado por un solo proyecto de liberación y de-colonización, y no podría ser un mundo policéntrico incluido en las categorías europeas de pensamiento, a la manera del cosmopolitanismo kantiano. Un mundo en el cual muchos mundos puedan coexistir sólo puede lograrse mediante un trabajo compartido y metas comunes en la diversidad, entre quienes habitan las fronteras o, habitando el territorio (Europa o Estados Unidos), Comienzan a habitar las fronteras creadas por la inmigración.” (125)

Hay cierta falsedad cuando se parte de la identidad nacional, de una Nación construida sobre las ruinas de la colonialidad del poder y la emergencia de un proyecto hegemónico de las burguesías nacionales que construyen la identidad ideológica, falsa, a imagen y semejanza de sus aspiraciones de elite, de las elites criollas sobre las cuales se fundó el estado-nación moderno en los países colonizados. La crisis de los estadosnacionales es evidente pero también la crisis de la transnacionalización de las cosas es igualmente evidente por fracturada y fracturante, porque parte del mismo episteme colonial imperialista, en donde en el concierto de la comunidad de naciones se busca imaginar un modelo sociedad como el de la comunidad europea, egocentrista y teocentrista.

Para nosotros, el espacio de libertad es individual y colectivo, parte del sujeto y no se desprende nunca de las intersubjetividades, es una subjetividad colectiva, es como todo lo humano, un producto de las culturas, hemos tratado de mostrar sucintamente como la humanidad es un hacer y rehacer de culturas, y con ese entramado simbólico se va construyendo el mundo material, el de las relaciones sociales y el de los imaginarios colectivos en la síntesis fugaz del espacio tiempo. Así, de esta manera, las llamadas identidades nacionales son una falacia histórica, pues son en realidad, identidades culturales que se resumen, solo en un instante de un territorio que arbitrariamente fue delimitado por el poder colonial, como ocurre, por ejemplo, con las fronteras (la balcanización) de los pequeños países centroamericanos, de tal manera que los fragmentos son totalidades de lo total. De ahí que la cultura se hilvana y no se puede desligar del poder (que tiende a fragmentar la cultura para ejercer su dominio como una totalidad impuesta, de las formas 
desiguales de la distribución del capital simbólico en una sociedad (Bourdieu, 1988), que tiende a fragmentarse separando a los distintos grupos étnico- sociales, tal y como lo hemos visto en el ejemplo de la inserción del inmigrante en el espacio de frontera, en donde frente a la necesidad humana de crear espacio de libertad, el poder tiende a la ruptura, a la fractura, a la segregación y a la exclusión de los otros, para mantener el control social y espacial (territorial) y esa figura volátil y borrosa de la identidad nacional.

\section{EI desmontaje teórico}

Creemos que las teorías son (además de todo lo que los diccionarios de filosofía y las escuelas epistemológicas puedan decir) juegos de espejos de la realidad, se juega con los conceptos y se construyen las explicaciones, que siempre tendrán algo de verdad y algo de mentira, como el claro -oscuro de los colores. Las "buenas" explicaciones se acercan a la verdad, pero fundamentalmente nos abren el universo de las preguntas para las nuevas explicaciones y así infinitamente. Para nosotros, las teorías existentes, las buenas teorías, son como las grandes ventanas para ver los panoramas, pero Marx, por ejemplo, se ocupó más del método y la buena explicación, que del dogma, y en alguna parte de sus costillas seguro que se ubicaba la idea de que las explicaciones no son eternas. Sabemos, también, de algunos otros filósofos que renunciaron a la filosofía porque creyeron que ya lo habían dicho todo, que ya no quedaba nada por decir. Las teorías son como pequeñas marionetas en el gran teatro del mundo con las que nos entretenemos mientras dura la función. Pero, la representación del mundo aunque nos ayude a comprenderlo, es sólo eso una representación, una representación necesaria aunque nunca será suficiente. Cuando en este ensayo partimos de las teorías y las explicaciones no pretendimos (que quede muy claro), cargar con ellas sobre las espaldas para que nos explicaran la vida cotidiana, ni aun en aquellos casos, como en ciertas filosofías o sociologías que buscan terminar con las separaciones, con los unilateralismos desde el sujeto al objeto, la estructura y el agente, o la explicación científica y la explicación vulgar. Nosotros no nos tomaríamos nada de esto muy en serio y sólo procuramos divertirnos ${ }^{20}$ en la explicación. Explicarnos el mundo a través de la representación teórica es una buena razón para vivir, pero la vida está en otra

20 Del latín divertere llevar por varios lados.

Geo UERJ - Ano 13, nº. 22, v. 1, 1º semestre de 2011 - ISSN 1981-9021

http://www.e-publicacoes.uerj.br/index.php/geouerj 
parte, y lo que hemos procurado mostrar en este ensayo es la relación dialéctica del encuentro y los desencuentros a veces abismales que se dan entre algunas formas de explicación, entre los papeles oficiales y la vida de las personas y queríamos ver dónde se producen las rupturas, que tarde o temprano siempre ocurren en el movimiento de la cosas, en las acciones, en la historia, en las interacciones, en las estructuras.

Esto es un juego inacabable, fascinante, que debería tener como una finalidad intermedia, en el caso particular de los migrantes, contribuir allí donde se producen las rupturas, es decir en el juego de intereses de los Estados y su ejercicio del poder, en los intereses de la acumulación capitalista a escala mundial y la crisis global del capitalismo, en las contradicciones entre el orden jurídico y la vida cotidiana, allí en esas tensiones, que son tensiones de clase, tensiones étnicas, tensiones en la relación sociedad - naturaleza, tensiones entre el mundo local y el mundo global, entre otras, contribuir allí, en fin, a seguir creando espacios de libertad.

\section{REFERENCIAS}

Alvarenga, P. (1997). Conflictiva convivencia: los nicaragüenses en Costa Rica. Cuaderno de Ciencias Sociales, 101, FLACSO, San José, Costa Rica.

Alvarenga, P. (2000). Trabajadores inmigrantes en la caficultura. Cuaderno de Ciencias Sociales, 116, FLACSO, San José, Costa Rica.

Alvarenga, P. (s.f.) Los migrantes nicaragüenses en Costa Rica. En Istmo. Revista virtual de estudios literarios y culturales centroamericanos. Recuperado el 2 de marzo del 2011 de http://www.google.co.cr/search?q=trabajadores+nicaraguenses+en+costa+ric a\&hl=es\&client=firefox-a\&rls=org.mozilla:es-ES:official\&channel=s\&prm

Arrieta, O. (2000) Fuerza de trabajo nicaragüense en Guanacaste. En Revista Geográfica ce América Central, 38, 7-25. 
Asamblea Legislativa de la República de Costa Rica [ALRCR] (2009) ley general de migración y extranjería (Ley No 8764). San José, C. R.: Asamblea Legislativa de la República de Costa Rica. [Aprobada a los cuatro días del mes de agosto del dos mil nueve]

Atilli, A. (2010). ¿ ¿Hacia un nuevo orden? Perspectiva global y política transnacional. En A. Hernández; A. Timate -Welsh \& M. Alcántara (Comp.). La reconfiguración neoliberal en América Latina. Mexico: Universidad Autónoma Metropolitana.

Avendaño, N. (2010). Diálogo y fraternidad entre nicas y ticos. Recuperado el 2 de marzo del 2011 de http://www.conexiones.com.ni/blog.php?id=23

Badilla, M. (s.f.) ¿Trabajo para extranjeros en Costa Rica? En http://www.casadelujo.com/public/1783.cfm Recuperado el 01 de marzo del 2011.

Beck, Ulrich (2004) Poder y contrapoder en la era global. La nueva economía política mundial. España: Paidós. [Capítulo VIII: Pequeño discurso fúnebre en la cuna de la era cosmopolita.)

Bourdieu, P. (1988). La distinción. Madrid, ES.: Taurus

Bourdieu, P. (1991).El sentido práctico. Madrid, ES.: Taurus

Bourdieu, P. [1992](1996). Las reglas del arte: génesis y estructura del campo literario. Barcelona, ES.: Anagrama.

Bourdieu, P. (1997). Espacio social y espacio simbólico. En Razones prácticas. Barcelona, ES.: Anagrama.

Bourdieu, P (1988a) Cosas dichas. Ed. Gedisa S.A. Buenos Aires, Argentina.

Borgino, N. \& Lauthelin, V. (1994) La cerámica del sitio Papagayo, Bahía Culebra, Costa Rica. En Vínculos, Revista de Antropología del Museo Nacional de Costa Rica.

Cabrera, R. (2007) Tierra y ganadería en Guanacaste. Cartago: Editorial Tecnológica de Costa Rica.

Chapman, A. (1960) Los Nicarao y los Chorotega según las fuentes históricas. San José, publicaciones de la Universidad de Costa Rica, (Serie Historia y Geografía $\left.\mathrm{N}^{\circ} 4\right)$ 
Concepción, L. (2010). Gobernanza y democracia en América Latina en un contexto de globalización. En L. Concepción \& P. Moctezuma (Comp.). Gobernanza global y democracia. México: Universidad Autónoma de Baja California.

Cranshaw, M. I. \& Morales, A. (1998). Mujeres Adolescentes y Migración entre Nicaragua y Costa Rica. San José, Costa Rica: FLACSO- Programa Mujeres Adolescentes y Consejo de Integración Social del SICA, San José.

Delanty, G. (2008). Fronteras: Transitoriedad y dinámicas interculturales. La imaginación cosmopolita. Revista CIDOB d'afers internacionals, 82-83, 35-49. $\begin{array}{llllll}\text { Recuperado el } & 3 & \text { de }\end{array}$ http://www.raco.cat/index.php/RevistaCIDOB/article/viewFile/117024/147 946

De la Torre, V. (s.f.). Ciudadanía mundial sin Estado mundial: la mundialización de los movimientos sociales y la reconfiguración de su relación con los Estados. México: Universidad de Colima.

Edelman, M. (2005). Don Chico y El Diablo: dimensiones de etnia, clase y género en las narrativas campesinas guanacastecas del siglo XX. En Molina \& Palmer (eds.) El paso del cometa. Estado, política social y culturas populares en Costa Rica $\quad$ (1800 1950). San José, C.R.: Euned.

Edelman, M. (1992). The Logic of the Latifundio. The Large State of Northwestern Costa Rica Since the Late Nineteenth Century. Stanford, California: Standford University Press.

Ferrero, L. (1979). Los Chorotegas. En LEGO, Revista de Información Bibliográfica Cultural Centroamericana, San José, Costa Rica.

Ferrero, L. (2000) Costa Rica precolombina. (6 ${ }^{\text {a }}$ reimpresión), San José, CR.: Editorial Costa Rica.

Ferrero, M. (2010). Gobernando (en) un mundo en globalización. Una mirada conceptual a la gobernanza desde las Relaciones Internacionales. En L. Concepción \& P. Moctezuma (Comp.). Gobernanza global y democracia. México: Universidad Autónoma de Baja California.

García Canclini, N. (1990). Culturas Híbridas, estrategias para entrar y salir de modernidad. México, D.F.: Editorial Grijalbo. 
García Canclini, N. (2004). Diferentes, Desiguales y Desconectados: mapas de la interculturalidad. Barcelona: Editorial Gedisa.

García Canclini, N. (2007). Néstor García Canclini, Noticias recientes sobre la hibridación. Recuperado el 13 de marzo del 2011 del sitio Web de Agitadores culturales. Artículos. Espacio para la difusión y reflexión sobre el arte, la literatura, la sociedad y la gestión cultural http://agitadoresculturales.blogspot.com/2007/01/nstor-garca-canclini- noticiasrecientes.html

García, P. (2008). Modernidad, ciudadanía y multiculturalismo. Las transformaciones de la identidad. En RIFP, 32. México.

García, E. \& Soto, Y. (1980). Monografía del cantón de Liberia. Heredia, Costa Rica, Centro de Estudios Generales, Unidad Coordinadora de Investigaciones, Universidad Nacional.

Grosfoguel, R. (2010). Descolonizando los paradigmas de la economía política: transmodernidad, pensamiento fronterizo y colonialidad global. University of California Berkeley.

Gudmonson, L. (1978). La ganadería guanacasteca en la época de la independencia: la hacienda de San Juan de Dios, 1815 -1835. En L. Gudmonson. Estratificación socio racial y económica de Costa Rica: 1700 1850. San José, C.R.: Euned.

Habermas, J. (1998). Ciudadanía e identidad nacional. Reflexiones sobre el futuro europeo. En: Habermas, Jurgen. (1998). Factibilidad y validez. España: Trotta.

Heller, A. (1991). Historia y futuro ¿sobrevivirá la modernidad? Barcelona, ES.: Península.

Heller, A. (1994). Sociología de la vida cotidiana. Barcelona: Península.

Hernández, A. (2010)¿Éxito o fracaso del neoliberalismo? En A. Hernández; A. Timate -Welsh; M. Alcántara (Comp.). La reconfiguración neoliberal en América Latina. México: Universidad Autónoma Metropolitana.

Ibarra, E. (2001). Fronteras étnicas en la conquista de Nicaragua y Nicoya. Entre la solidaridad y el conflicto 800 d. C. -1544. San José, C.R.: Editorial de la Universidad de Costa Rica. 
Keohane, R. \& Nye, J. (2009). La interdependencia en la política mundial. En A. Borja (Comp.). Interdependencia, cooperación y globalismo. México: Centro de Investigación y Docencia Económicas.

Keohane, R. (2009). La soberanía, la interdependencia y las instituciones internacionales.

En A. Borja (Comp.). Interdependencia, cooperación y globalismo. México: Centro de Investigación y Docencia Económicas.

Keohane, R. \& Nye J. (2009). La gobernanza en un mundo parcialmente globalizado. En A. Borja (Comp.). Interdependencia, cooperación y globalismo. México: Centro de Investigación y Docencia Económicas.

Lange, F. (1994). Evaluación histórica del concepto Gran Nicoya. En Vínculos. Revista de Antropología del Museo Nacional de Costa Rica, 1-2(18) (19). Taller sobre el futuro de las investigaciones arqueológicas y etnológicas en Gran Nicoya. Costa Rica -Nicaragua.

Luque, J. (2010). Migración, ciudadanía y democracia. La estructura política del neoliberalismo en América Latina. En A. Hernández, A. Timate -Welsh \& M. Alcántara (Comp.). La reconfiguración neoliberal en América Latina. Mexico: Universidad Autónoma Metropolitana.

Massey, D. (1995). The conceptualization of place. In Massey, D. y Jess, P., (eds) A place in the world. Oxford: Oxford University Press, p. 45-85.

Matarrita, M. (1980). La hacienda ganadera colonial en el Corregimiento de Nicoya, siglo XVII. Tesis de Licenciatura no publicada, Universidad de Costa Rica, San José, Costa Rica, Escuela de Historia y Geografía, Facultad de Ciencias Sociales.

Mendieta, E. (2010) Del cosmopolitismo imperial al cosmopolitismo dialógico: humildad, solidaridad y paciencia. En Rodríguez, I. \& Martínez, J. (Eds.) Estudios

Trasatlánticos postcoloniales. Vol. 1. Universidad Autónoma Metropolitana, División de ciencias sociales y humanidades: Anthropos. (pp. 293-316). [Hemos consultado la versión de http://www.filosoficas.unam.mx/ afmbib/mayteAFM/Ponencias/24032.pdf Recuperada el 27 de febrero del 2011]

Mignolo, W. (2010). Desobediencia epistémica retórica de la modernidad, lógica de la colonialidad y gramática de la descolonialidad. Buenos Aires: Ediciones del Signo. 
Morales, A. (coord.). (1999). "Análisis de los alcances sociales y del impacto del régimen de excepción migratoria para los inmigrantes de origen centroamericano

en Costa Rica" Realizado en setiembre 1999, por la Facultad Latinoamericana de Ciencias Sociales (FLACSO) con el auspicio de la Organización INternacional de Migraciones (OMC). Informe especial: Nicaragüenses en Costa Rica.

Morales, A. (2007). La Diáspora de la Posguerra. Regionalismo de los migrantes y dinámicas territoriales en América Central. San José, Costa Rica: FLACSO.

Morales, A. \& Castro, C. (2002). Redes transfronterizas. Sociedad, empleo y migración entre Nicaragua y Costa Rica.” San José, Costa Roica: FLACSO.

Nussbaum, M. [Joshua Cohen Comp.] (1999). Los límites del patriotismo: identidad, pertenencia y "ciudadanía mundial". Barcelona: Paidós Ibérica.

Pereira, J. C. (2008). [coord.]. Diccionario de relaciones exteriores y política exterior. Barcelona: Ariel

Quijano, A. (2000). Colonialidad del poder y clasificación social. En: Journal of World Systems Research,2 (VI), 342-386. [Special Issue: Festschrift for Inmanuel Wallesrstein - Part. I.]

Quintero, P. (2010). Notas sobre la teoría de la colonialidad del poder y la estructuración de la sociedad en América Latina. En Papeles de Trabajo,19, Junio 2010 - ISSN 1852-4508 Centro de Estudios Interdisciplinarios en Etnolingüística y Antropología Socio-Cultural.

Rodríguez, E. (1998). La vida cotidiana de La Laguna en la prensa del siglo XIX. Revista LATINA de comunicación social, 5, 1-5. Recuperado el 20 de enero del 2011 de http://www.lazarillo.com/latina/a/90enrique.htm

Rojo, A. (2010). Globalización y crisis de la política: la necesidad de instaurar el espacio público. En L. Concepción \& P. Moctezuma (Comp.). Gobernanza global y democracia. México: Universidad Autónoma de Baja California.

Said, E. (2005). Cultura, identidad e historia. En G. Schröder \& H. Breuninger, Helga (comps.). Teoría de la cultura. Un mapa de la cuestión. México: Fondo de Cultura Económica.

Santos, M. (1996). Metamorfosis del espacio habitado. Barcelona: Oikos-tau. 
Sequeira, W. (1985). La hacienda ganadera en Guanacaste. Aspectos económicos y sociales. 1850 -1900. San José, C.R.: Euned.

Touraine, A. (1997). ¿Podremos vivir juntos? Iguales y diferentes. Madrid, España, Ed. PPC

Touraine, A. (2002). Crítica de la modernidad. 2a . ed. México: Fondo de Cultura Económica.

Torres, A.; \& Torres, J. C. (2000). Subjetividad y sujetos sociales en la obra de Hugo Zemelman. En publicacion: Folios,12. UPN, Universidad Pedagógica Nacional:

Colombia. 2000 0123-4870. recuperado el 13 de marzo del 2011 de http://w3.pedagogica.edu.co/storage/folios/articulos/fol12_04arti.pdf

Viejo, R. (2010). Soberanía y gobernanza en la era global: crisis biopolítica en la forma Estado y modo de mando en el capitalismo cognitivo. En L. Concepción \& P. Moctezuma (Comp.). Gobernanza global y democracia. México: Universidad Autónoma de Baja California.

Villarreal, R. (2010). Mano de obra nicaragüense a Costa Rica. Recuperado el 17 de marzo del 2011 www.laprensa.com.ni/2010/12/14/departamentos/46302.

\section{Entrevistas realizadas:}

Se realizaron entrevistas abiertas informales a ocho mujeres nicaragüenses, utilizando únicamente libreta de apuntes: dos trabajadoras domésticas, una mujer que trabaja en conserjería de un edificio de oficinas, dos trabajadoras en locales comerciales, una vendedora ambulante y dos obreras en actividades agroindustriales.

Se utilizó la misma forma para entrevistar a nueve varones: dos trabajadores mecánicos, un trabajador ebanista, dos trabajadores de la construcción, dos trabajadores que parcialmente se dedican a labores agrícolas y a la venta ambulante de música y películas pirateadas y dos trabajadores informales que realizan reparaciones varias, labores de limpieza y jardinería de manera temporal. 
En todos los casos logramos conversar en dos ocasiones con cada uno de ellos y ellas. Cada sesión (encuentro) fue de poco menos de una hora y se procuraba siempre guiar la conversación hacia seis temas generales que fueron: a. Estatus migratorio y situación de empleo, b. años de vivir en Costa Rica y percepción de su condición como ciudadano o ciudadana, c. qué le motivó a dejar su tierra y venir a este país. d. sobre su entorno familiar aquí y en Nicaragua, e. nivel de satisfacción con su vida en Costa Rica y en Nicaragua, f. sobre sus planes para los próximos tres años.

Se realizó una entrevista formal, sobre la situación de los migrantes nicaragüenses en la Región Pacífico Norte a Mateo Chaves Morera. (3 de marzo del 2011) Entrevista personal. [Director Delegación Regional de Migración en Liberia, Guanacaste] [mchaves@migración.go.cr]

OACH/oach/ BIFWS-OACH-07042011

Enviado para publicação em julho de 2011.

Aceito para publicação em agosto de 2011. 